Prepared in cooperation with the Natural Resources Conservation Service, Texas State Soil and Water Conservation Board, Victoria County Groundwater Conservation District, Victoria Soil and Water Conservation District, and the San Antonio River Authority

\title{
Effects of Huisache Removal on Rangeland Evapotranspiration in Victoria County, South-Central Texas, 2015-18
}

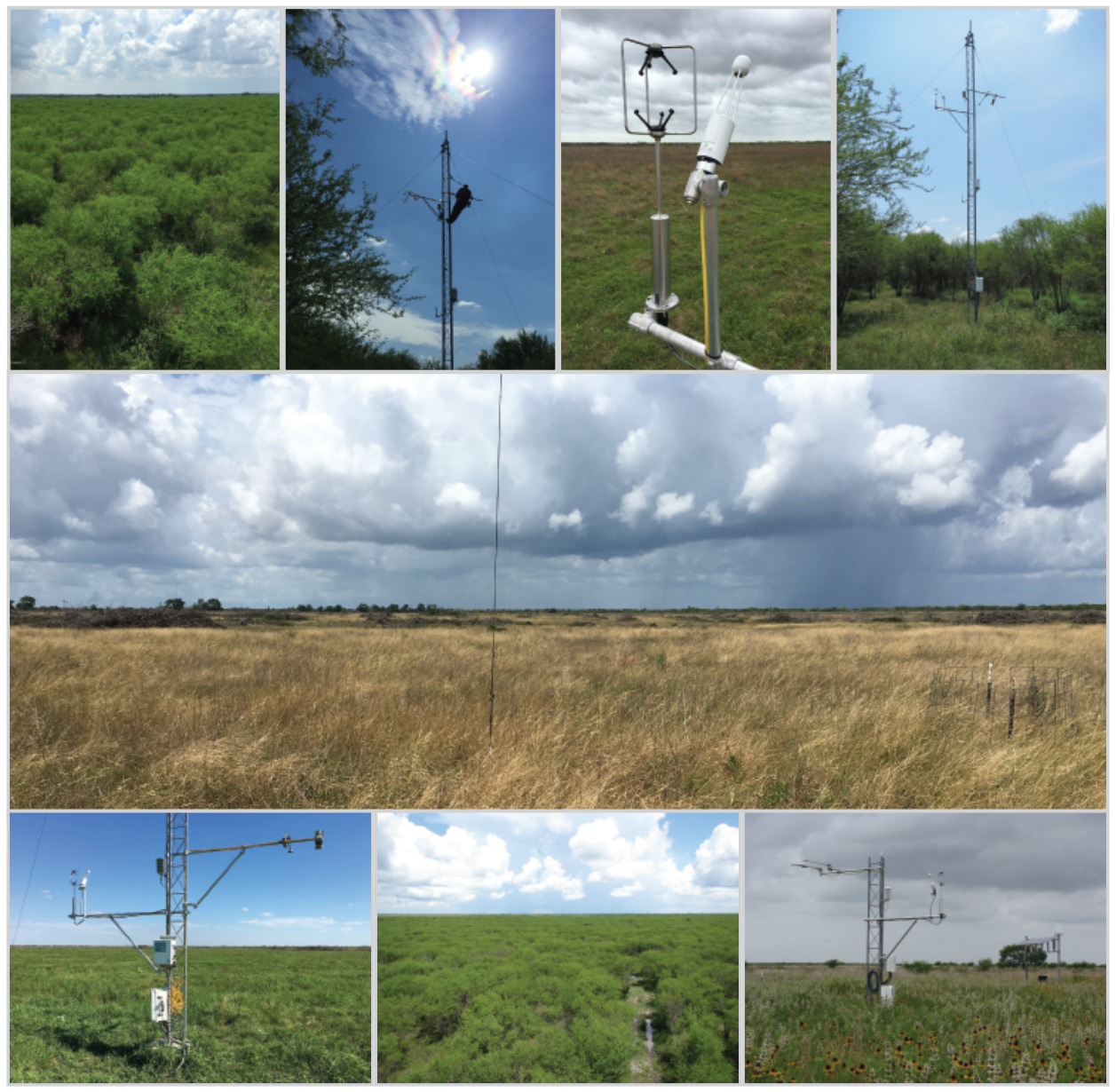

Scientific Investigations Report 2020-5008 
Cover.

\section{Top, from left to right}

1. Photograph showing the huisache site, U.S. Geological Survey (USGS) site 283526096594800 evapotranspiration (ET) gage (the treatment site), near McFaddin, Texas, prior to huisache removal at the site (photograph by Richard Slattery, USGS, August 31, 2016).

2. Photograph showing the huisache site ET gage prior to huisache removal at the site (photograph by George Umphres, USGS, October 6, 2015).

3. Photograph showing the sonic anemometer and gas analyzer at the grassland site, USGS site 283534097002100 ET gage (the reference site), near McFaddin, Texas (photograph by Richard Slattery, USGS, March 23, 2016).

4. Photograph showing the huisache site ET gage prior to huisache removal at the site (photograph by George Umphres, USGS, July 30, 2015).

\section{Center}

5. Photograph showing the huisache site after huisache removal (photograph by George Umphres, USGS, May 23, 2018).

\section{Bottom, from left to right}

6. Photograph showing the huisache site ET gage after huisache removal at the site (photograph by George Umphres, USGS, September 7, 2017).

7. Photograph showing the huisache site prior to huisache removal (photograph by George Umphres, USGS, June 24, 2015).

8. Photograph showing the grassland site ET gage (photograph by Richard Slattery, USGS, May 28, 2015). 


\section{Effects of Huisache Removal on Rangeland Evapotranspiration in Victoria County, South-Central Texas, 2015-18}

By Richard N. Slattery, Darwin J. Ockerman, Matt Bromley, Justin Huntington, and John R. Banta

Prepared in cooperation with the Natural Resources Conservation Service, Texas State Soil and Water Conservation Board, Victoria County Groundwater Conservation District, Victoria Soil and Water Conservation District, and the San Antonio River Authority

Scientific Investigations Report 2020-5008 


\title{
U.S. Department of the Interior DAVID BERNHARDT, Secretary
}

\author{
U.S. Geological Survey \\ James F. Reilly II, Director
}

\section{U.S. Geological Survey, Reston, Virginia: 2020}

For more information on the USGS - the Federal source for science about the Earth, its natural and living resources, natural hazards, and the environment-visit https://www.usgs.gov or call 1-888-ASK-USGS.

For an overview of USGS information products, including maps, imagery, and publications, visit https://store.usgs.gov.

Any use of trade, firm, or product names is for descriptive purposes only and does not imply endorsement by the U.S. Government.

Although this information product, for the most part, is in the public domain, it also may contain copyrighted materials as noted in the text. Permission to reproduce copyrighted items must be secured from the copyright owner.

Suggested citation:

Slattery, R.N., Ockerman, D.J., Bromley, M., Huntington, J., and Banta, J.R., 2020, Effects of huisache removal on rangeland evapotranspiration in Victoria County, south-central Texas, 2015-18: U.S. Geological Survey Scientific Investigations Report 2020-5008, 27 p., https://doi.org/10.3133/sir20205008.

The associated data release is

Slattery, R.N., 2020, Evapotranspiration measured at two rangeland sites in Victoria County, south-central Texas, 2015-2018: U.S. Geological Survey data release, https://doi.org/10.5066/P9500SRE.

ISSN 2328-0328 (online) 


\section{Acknowledgments}

The authors thank McFaddin Enterprises Ltd. for allowing installation of the evapotranspiration stations on the McFaddin ranch, for providing ongoing access to the sites for operation and maintenance of the equipment, and for their contribution of equipment and resources needed for the huisache removal surrounding the huisache site evapotranspiration station. 



\section{Contents}

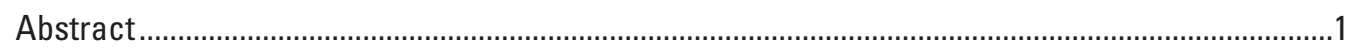

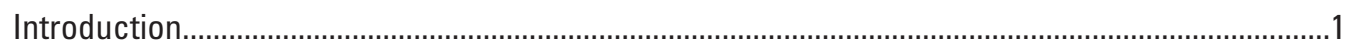

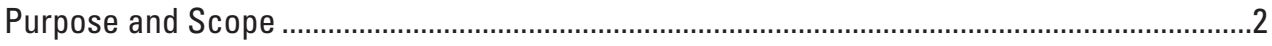

Description of Study Area .......................................................................................................

Data-Collection Methods......................................................................................................................

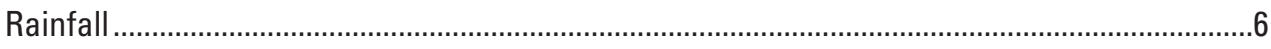

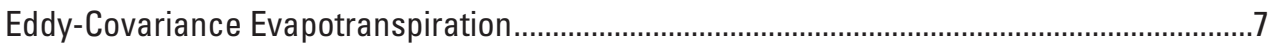

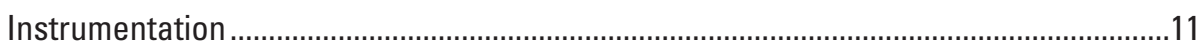

Data Processing.......................................................................................................12

Quality Assurance of Energy Flux and Meteorological Data ................................................12

Source Area of Measurements ............................................................................................13

Evapotranspiration Data ..........................................................................................................13

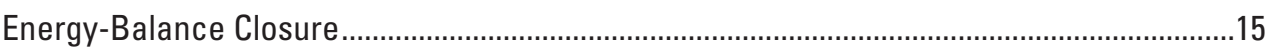

Remote Sensing of Evapotranspiration.....................................................................................16

Effects of Huisache Removal on Evapotranspiration .....................................................................17

Mapping Evapotranspiration by Remote Sensing ..............................................................................

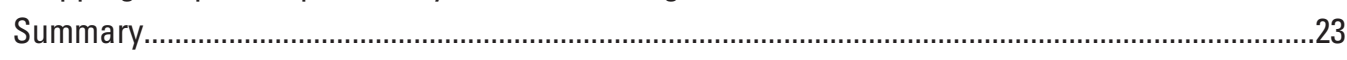

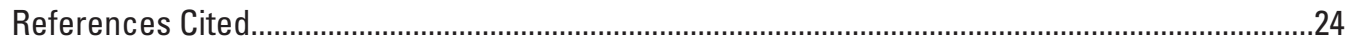

\section{Figures}

1. Map showing locations of evapotranspiration monitoring sites and other data-collection stations providing data that were used in the study, Victoria

2. Photograph showing landscape surrounding the instrument tower at the grassland site evapotranspiration station, Victoria County, Texas, March 2015 ...............5

3. Photograph showing landscape beginning to leaf out at the huisache site evapotranspiration station, Victoria County, Texas, March 2015 ......................................

4. Photograph showing landscape in full leaf out surrounding the huisache site evapotranspiration station, Victoria County, Texas, August 2016 ...................................6

5. Photograph showing landscape surrounding the huisache site evapotranspiration station, Victoria County, Texas, on February 2, 2017, after huisache removal .................7

6. Image showing satellite view of evapotranspiration measurement sites, March 25, 2017, Victoria County, Texas...

7. Photograph showing landscape surrounding the huisache site evapotranspiration station after huisache removal, April 2017, Victoria County, Texas ...

8. Graph showing source-area contributions of average daytime cumulative turbulent flux for the grassland and huisache evapotranspiration sites, Victoria County, Texas, before and after huisache removal..

9. Graph showing daily eddy-covariance evapotranspiration values at the grassland and huisache sites, Victoria County, Texas, March 2015-August 2018.

10. Graph showing three-month moving average of the monthly energy-balance ratio, grassland site and huisache site, Victoria County, Texas, March 2015August 2018. 
11. Graphs showing comparison of corrected eddy-covariance monthly evapotranspiration and remotely sensed monthly evapotranspiration at the grassland site and the huisache site, Victoria County, Texas, March 2015August 2018.

12. Graph showing monthly cumulative difference in evapotranspiration between huisache and grassland sites, by eddy-covariance and remotely sensed evapotranspiration methods, Victoria County, Texas, March 2015-August 2018

13. Map showing remotely sensed 2015 annual evapotranspiration rates for the study sites and surrounding area, Victoria County, Texas

\section{Tables}

1. Annual (2015-18) and long-term average annual (1962-2018) rainfall at Victoria Regional Airport, Texas.

2. Stations providing data for the rangeland evapotranspiration study, Victoria County, Texas, March 2015-August 2018.

3. Instruments used to measure evapotranspiration, energy balance, and rainfall at eddy-covariance evapotranspiration sites, Victoria County, Texas

4. Number of daily evapotranspiration values collected at the grassland and huisache sites, Victoria County, Texas, March 2015-August 2018.

5. Summary of average energy-balance data and calculated energy-balance ratio at the grassland and huisache evapotranspiration sites, March 2015-August 2018......15

6. Summary of rainfall and evapotranspiration totals for the grassland and huisache study sites, March 2015-August 2018

7. Selected statistics for the monthly difference in evapotranspiration between the huisache site and grassland site ( $E T_{\text {huisache }}-\mathrm{ET}_{\text {grassland }}$ ) before and after huisache removal .....

8. Average monthly difference between huisache site and grassland site evapotranspiration before huisache removal (pre-removal period) and after huisache removal (post-removal period) for eddy-covariance and remote-sensing estimates. 


\section{Conversion Factors}

International System of Units to U.S. customary units

\begin{tabular}{|c|c|c|}
\hline Multiply & By & To obtain \\
\hline \multicolumn{3}{|c|}{ Length } \\
\hline centimeter $(\mathrm{cm})$ & 0.3937 & inch (in.) \\
\hline millimeter $(\mathrm{mm})$ & 0.03937 & inch (in.) \\
\hline meter $(\mathrm{m})$ & 3.281 & foot $(\mathrm{ft})$ \\
\hline kilometer $(\mathrm{km})$ & 0.6214 & mile (mi) \\
\hline \multicolumn{3}{|c|}{ Area } \\
\hline square meter $\left(\mathrm{m}^{2}\right)$ & 0.0002471 & acre \\
\hline hectare (ha) & 2.471 & acre \\
\hline square kilometer $\left(\mathrm{km}^{2}\right)$ & 247.1 & acre \\
\hline square meter $\left(\mathrm{m}^{2}\right)$ & 10.76 & square foot $\left(\mathrm{ft}^{2}\right)$ \\
\hline hectare (ha) & 0.003861 & square mile $\left(\mathrm{mi}^{2}\right)$ \\
\hline square kilometer $\left(\mathrm{km}^{2}\right)$ & 0.3861 & square mile $\left(\mathrm{mi}^{2}\right)$ \\
\hline \multicolumn{3}{|c|}{ Volume } \\
\hline cubic centimeter $\left(\mathrm{cm}^{3}\right)$ & 0.06102 & cubic inch $\left(\mathrm{in}^{3}\right)$ \\
\hline liter (L) & 61.02 & cubic inch $\left(\mathrm{in}^{3}\right)$ \\
\hline cubic meter $\left(\mathrm{m}^{3}\right)$ & 35.31 & cubic foot $\left(\mathrm{ft}^{3}\right)$ \\
\hline cubic kilometer $\left(\mathrm{km}^{3}\right)$ & 0.2399 & cubic mile $\left(\mathrm{mi}^{3}\right)$ \\
\hline cubic meter $\left(\mathrm{m}^{3}\right)$ & 0.0008107 & acre-foot (acre-ft) \\
\hline \multicolumn{3}{|c|}{ Mass } \\
\hline $\operatorname{gram}(\mathrm{g})$ & 0.03527 & ounce, avoirdupois (oz) \\
\hline kilogram (kg) & 2.205 & pound, avoirdupois (lb) \\
\hline \multicolumn{3}{|c|}{ Pressure } \\
\hline kilopascal (kPa) & 0.009869 & atmosphere, standard (atm) \\
\hline kilopascal (kPa) & 20.88 & pound per square foot $\left(\mathrm{lb} / \mathrm{ft}^{2}\right)$ \\
\hline kilopascal $(\mathrm{kPa})$ & 0.1450 & pound per square inch $\left(\mathrm{lb} / \mathrm{ft}^{2}\right)$ \\
\hline \multicolumn{3}{|c|}{ Density } \\
\hline kilogram per cubic meter $\left(\mathrm{kg} / \mathrm{m}^{3}\right)$ & 0.06242 & pound per cubic foot $\left(\mathrm{lb} / \mathrm{ft}^{3}\right)$ \\
\hline gram per cubic centimeter $\left(\mathrm{g} / \mathrm{cm}^{3}\right)$ & 62.4220 & pound per cubic foot $\left(\mathrm{lb} / \mathrm{ft}^{3}\right)$ \\
\hline \multicolumn{3}{|c|}{ Energy } \\
\hline joule $(\mathrm{J})$ & 0.2390 & calorie (cal) \\
\hline watt per square meter $\left(\mathrm{W} / \mathrm{m}^{2}\right)$ & 0.0222 & $\begin{array}{l}\text { calorie per second per square foot } \\
{\left[(\mathrm{cal} / \mathrm{s}) / \mathrm{ft}^{2}\right]}\end{array}$ \\
\hline \multicolumn{3}{|c|}{ Frequency } \\
\hline hertz $(\mathrm{Hz})$ & 1.0 & cycles per second (cps) \\
\hline
\end{tabular}


U.S. customary units to International System of Units

\begin{tabular}{|c|c|c|}
\hline Multiply & By & To obtain \\
\hline \multicolumn{3}{|c|}{ Length } \\
\hline inch (in.) & 2.54 & centimeter $(\mathrm{cm})$ \\
\hline inch (in.) & 25.4 & millimeter (mm) \\
\hline foot $(\mathrm{ft})$ & 0.3048 & meter $(\mathrm{m})$ \\
\hline mile (mi) & 1.609 & kilometer (km) \\
\hline \multicolumn{3}{|c|}{ Area } \\
\hline acre & 4,047 & square meter $\left(\mathrm{m}^{2}\right)$ \\
\hline acre & 0.004047 & square kilometer $\left(\mathrm{km}^{2}\right)$ \\
\hline square foot $\left(\mathrm{ft}^{2}\right)$ & 0.09290 & square meter $\left(\mathrm{m}^{2}\right)$ \\
\hline square inch $\left(\mathrm{in}^{2}\right)$ & 6.452 & square centimeter $\left(\mathrm{cm}^{2}\right)$ \\
\hline square mile $\left(\mathrm{mi}^{2}\right)$ & 259.0 & hectare (ha) \\
\hline square mile $\left(\mathrm{mi}^{2}\right)$ & 2.590 & square kilometer $\left(\mathrm{km}^{2}\right)$ \\
\hline \multicolumn{3}{|c|}{ Volume } \\
\hline cubic inch $\left(\mathrm{in}^{3}\right)$ & 16.39 & cubic centimeter $\left(\mathrm{cm}^{3}\right)$ \\
\hline cubic inch $\left(\mathrm{in}^{3}\right)$ & 0.01639 & liter $(\mathrm{L})$ \\
\hline cubic foot $\left(\mathrm{ft}^{3}\right)$ & 0.02832 & cubic meter $\left(\mathrm{m}^{3}\right)$ \\
\hline cubic mile $\left(\mathrm{mi}^{3}\right)$ & 4.168 & cubic kilometer $\left(\mathrm{km}^{3}\right)$ \\
\hline acre-foot (acre-ft) & 1,233 & cubic meter $\left(\mathrm{m}^{3}\right)$ \\
\hline \multicolumn{3}{|c|}{ Mass } \\
\hline ounce, avoirdupois (oz) & 28.35 & $\operatorname{gram}(\mathrm{g})$ \\
\hline pound, avoirdupois (lb) & 0.4536 & kilogram $(\mathrm{kg})$ \\
\hline \multicolumn{3}{|c|}{ Pressure } \\
\hline atmosphere, standard (atm) & 101.3 & kilopascal (kPa) \\
\hline pound per square foot $\left(\mathrm{lb} / \mathrm{ft}^{2}\right)$ & 0.04788 & kilopascal (kPa) \\
\hline pound per square inch $\left(\mathrm{lb} / \mathrm{in}^{2}\right)$ & 6.895 & kilopascal $(\mathrm{kPa})$ \\
\hline \multicolumn{3}{|c|}{ Density } \\
\hline pound per cubic foot $\left(\mathrm{lb} / \mathrm{ft}^{3}\right)$ & 6,020 & gram per cubic meter $\left(\mathrm{kg} / \mathrm{m}^{3}\right)$ \\
\hline pound per cubic foot $\left(\mathrm{lb} / \mathrm{ft}^{3}\right)$ & 0.01602 & gram per cubic centimeter $\left(\mathrm{g} / \mathrm{cm}^{3}\right)$ \\
\hline \multicolumn{3}{|c|}{ Energy } \\
\hline calorie (cal) & 4.184 & joule $(\mathrm{J})$ \\
\hline calorie per second per square foot $\left[(\mathrm{cal} / \mathrm{s}) / \mathrm{ft}^{2}\right]$ & 45.045 & watt per square meter $\left(\mathrm{W} / \mathrm{m}^{2}\right)$ \\
\hline
\end{tabular}

Temperature in degrees Celsius $\left({ }^{\circ} \mathrm{C}\right)$ may be converted to degrees Fahrenheit $\left({ }^{\circ} \mathrm{F}\right)$ as follows:

${ }^{\circ} \mathrm{F}=\left(1.8 \times{ }^{\circ} \mathrm{C}\right)+32$.

Temperature in degrees Fahrenheit $\left({ }^{\circ} \mathrm{F}\right)$ may be converted to degrees Celsius $\left({ }^{\circ} \mathrm{C}\right)$ as follows:

${ }^{\circ} \mathrm{C}=\left({ }^{\circ} \mathrm{F}-32\right) / 1.8$. 


\section{Datum}

Vertical coordinate information is referenced to either the National Geodetic Vertical Datum of 1929 (NGVD 29) or the North American Vertical Datum of 1988 (NAVD 88).

Horizontal coordinate information is referenced to either the North American Datum of 1927 or the North American Datum of 1983 (NAD 83).

Altitude, as used in this report, refers to distance above the vertical datum.

\section{Abbreviations}

$\begin{array}{ll}\text { CIMEC } & \text { Calibration Using Inverse Modeling at Extreme Conditions } \\ \text { DRI } & \text { Desert Research Institute } \\ E B R & \text { energy-balance ratio } \\ \text { EC } & \text { eddy covariance } \\ \text { ET } & \text { evapotranspiration } \\ \text { ET }_{\mathrm{C}} & \text { corrected eddy-covariance evapotranspiration } \\ \mathrm{ET}_{\mathrm{EC}} & \text { eddy-covariance evapotranspiration } \\ E T_{r} & \text { daily reference evapotranspiration } \\ E T_{r} F & \text { fraction of daily reference evapotranspiration } \\ \mathrm{ET}_{\mathrm{RS}} & \text { remotely sensed evapotranspiration } \\ G & \text { soil heat flux } \\ H & \text { sensible-heat flux } \\ L E & \text { latent-heat flux } \\ \text { METRIC } & \text { Mapping Evapotranspiration at High Resolution With Internalized Calibration } \\ \text { NWS } & \text { National Weather Service } \\ R_{n} & \text { net radiation } \\ \text { SSEBop } & \text { Operational Simplified Surface Energy Balance } \\ \text { USGS } & \text { U.S. Geological Survey }\end{array}$





\title{
Effects of Huisache Removal on Rangeland Evapotranspiration in Victoria County, South-Central Texas, 2015-18
}

\author{
By Richard N. Slattery, Darwin J. Ockerman,' Matt Bromley, ${ }^{2}$ Justin Huntington, ${ }^{2}$ and John R. Banta'
}

\section{Abstract}

The U.S. Geological Survey and Desert Research Institute, in cooperation with the Natural Resources Conservation Service, Texas State Soil and Water Conservation Board, Victoria County Groundwater Conservation District, Victoria Soil and Water Conservation District, and the San Antonio River Authority, evaluated the hydrologic effects of Vachellia farnesiana var. farnesiana (huisache) removal on rangeland evapotranspiration in Victoria County, Texas. Measurements of evapotranspiration, rainfall, and related properties were made at two sites during March 2015 through August 2018. One site was predominantly grassland. The other site was dominated by dense huisache vegetation that was removed about halfway through the study period. The resulting evapotranspiration data were examined for differences between the locations and differences between the pre-removal (2015-16) and post-removal (2017-18) periods to assess the effects of huisache removal on evapotranspiration. Evapotranspiration measurements were made using the eddy-covariance technique and were supplemented by remote-sensing estimates of evapotranspiration derived from thermal and optical satellite images. A map of remotely sensed evapotranspiration was generated for the area surrounding the study sites for 2015 and demonstrates the capability of remote sensing to evaluate land-management effects on evapotranspiration for larger scale areas, such as a county or stream-basin area.

During the pre-removal period (March 2015December 2016), evapotranspiration was greater at the huisache site than at the grassland site. Evapotranspiration at the grassland site (average of the eddy-covariance evapotranspiration and average remotely sensed evapotranspiration) was 87.6 millimeters per month $(\mathrm{mm} / \mathrm{mo})$ and at the huisache site was $100.8 \mathrm{~mm} / \mathrm{mo}$, with the differences in evapotranspiration rates being attributed to the difference in site vegetation. After huisache was removed

${ }^{1}$ U.S. Geological Survey.

${ }^{2}$ Desert Research Institute. in January 2017, evapotranspiration at the huisache site was substantially lower than at the grassland site, the changes in evapotranspiration rates being attributed not only to removal of huisache vegetation but also to possible disruption of soil runoff and infiltration characteristics. During the post-removal period (February 2017-August 2018), evapotranspiration was $88.5 \mathrm{~mm} / \mathrm{mo}$ at the grassland site and $72.9 \mathrm{~mm} / \mathrm{mo}$ at the huisache site (average of the eddy-covariance and average remotely sensed evapotranspiration).

The monthly differences in evapotranspiration between the grassland and huisache sites, determined by eddy-covariance and remote-sensing methods, were statistically significant between the pre-removal and post-removal periods. Also, the pre-removal period provided the best conditions to evaluate the differences between huisache site and grassland site evapotranspiration. During the pre-removal period, evapotranspiration from the huisache site as measured by the eddy-covariance method was, on average, $10.7 \mathrm{~mm} / \mathrm{mo}$ greater than evapotranspiration measured at the grassland site. As determined by the average of the remotely sensed methods, huisache site evapotranspiration was $15.8 \mathrm{~mm} / \mathrm{mo}$ greater than grassland site evapotranspiration. These average differences in evapotranspiration rates by the two methods indicate that evapotranspiration at the grassland site was, on average, $13.2 \mathrm{~mm} / \mathrm{mo}$ less than that at the huisache site during the pre-removal period. This average difference in evapotranspiration rates also indicates potential increased groundwater recharge and (or) surface-water runoff at the grassland site.

\section{Introduction}

Brushy or woody plants in grassland prairies of the Southwestern United States have increased during the past 150 years (Van Auken, 2000). Historically, grassland prairies in Texas were often interspersed with stands of oak trees and used as rangelands for grazing domestic animals. Much of the historical oak-grassland land cover 
across Texas has undergone woody-plant encroachment attributed to fire suppression and overgrazing (Bray, 1904; Van Auken, 2000; Ansley and Hart, 2012). Some scientific studies have reported evidence that land use and altered vegetation composition may affect streamflow, downstream spring discharge, and groundwater recharge (Thurow and Hester, 1997; Tennesen, 2008; Saleh and others, 2009; Banta and Slattery, 2011).

Vachellia farnesiana var. farnesiana (huisache) is one type of woody plant that can overtake a grassland prairie in Texas, often in a generation, resulting in areas with diminished grazing benefits (Mutz and others, 1978; Bontrager and others, 1979). Huisache can grow 5-8 meters (m) tall, and its extensive root system is able to access both shallow soil water and deeper groundwater. Huisache is a prolific seed producer, and once established, it can outcompete native grasses for space (Teveni, 2017).

By removing woody vegetation such as huisache and allowing native grasses to reestablish, the hydrologic budget of the watershed might change to increase groundwater recharge and surface-water supply (Teveni, 2017). One method of documenting changes to the hydrologic budget resulting from differences in vegetative cover is by measuring evapotranspiration rates (Dugas and others, 1998).

Evapotranspiration is the combined processes of evaporation and transpiration wherein water is converted from a liquid to a vapor and is transferred from Earth's surface to the atmosphere. Evaporation occurs from open bodies of water, soil water, and water condensate on land and vegetation surfaces. Transpiration processes occur in plants, wherein liquid water is changed to a vapor as it passes through the stomata of the plant. Evapotranspiration rates are affected by available energy and water, as well as by air temperature, humidity, wind and air movement, soil moisture, depth to groundwater, and plant phenology (U.S. Geological Survey, 2019a). By quantifying evapotranspiration rates for different vegetative species, a better understanding of the hydrologic budget in a watershed is possible (Stannard and others, 2013).

Previous studies have shown that different vegetative land cover can affect evapotranspiration and might influence the hydrologic cycle (Tennesen, 2008; Saleh and others, 2009; Banta and Slattery, 2011). For example, at the Honey Creek State Natural Area, near Spring Branch, Tex., Juniperus ashei (Ashe juniper) was removed, and the post-brush-management hydrologic data exhibited a reduction in evapotranspiration compared to the pre-brush-removal period (Banta and Slattery, 2011). Similarly, in the North Concho River Basin near San Angelo, Tex., a reduction in evapotranspiration was observed after removal of genus Prosopis (mesquite) vegetation (Saleh and others, 2009).

The U.S. Geological Survey (USGS) and the Desert Research Institute (DRI), in cooperation with various Federal, State, and local agencies, studied the effects of huisache removal on evapotranspiration and the hydrologic budget on rangeland in Victoria County in south-central Texas during 2015-18. Federal, State, and local agencies that cooperated on the study were the Natural Resources Conservation Service, Texas State Soil and Water Conservation Board, Victoria County Groundwater Conservation District, Victoria Soil and Water Conservation District, and the San Antonio River Authority.

Quantifying evapotranspiration rates is essential for understanding the effects of woody-vegetation removal at a site (Dugas and others, 1998; Saleh and others, 2009; Banta and Slattery, 2011). Typically, the scales of evapotranspiration studies range from plot size (a few hectares) to small watershed size (less than 20 square kilometers $\left[\mathrm{km}^{2}\right]$ ). One concern of sitebased measurement studies of evapotranspiration is how to best incorporate measurements from smaller scale (plot or small watershed size) studies into larger scale studies that can then be used for basin-scale hydrologic models (Liu and others, 2016).

One technique to "scale up" from smaller scale studies is to use remote-sensing techniques based on satellite imagery (Liu and others, 2016). Satellite images have much larger footprints than do ground-based monitoring systems (for example, a Landsat satellite image covers approximately $33,000 \mathrm{~km}^{2}$ of Earth's surface) while maintaining relatively high spatial resolution (as detailed as $30 \times 30 \mathrm{~m}$ ) (National Aeronautics and Space Administration, 2019a). By using satellite images of surface temperature and surface reflectance, evapotranspiration rates can be estimated with the application of surface energy-balance models. Remote-sensing estimates are commonly used to complement and scale up ground-based measurements of evapotranspiration in space and time (Kustas and Norman, 2009). Spatial and temporal estimates of evapotranspiration derived from remote-sensing models can be incorporated into hydrologic models to support the model calibration process and ultimately improve estimates of the water budget and prediction of individual water budget variables, such as streamflow and groundwater recharge (Zhang and others, 2009; Szilagyi and Jozsa, 2013; Carroll and others, 2015). For example, two remote-sensing-based surface energy-balance models that have been extensively applied and assessed across the Western United States include the Mapping Evapotranspiration at High Resolution With Internalized Calibration (METRIC) model (Allen and others, 2007) and the Operational Simplified Surface Energy Balance (SSEBop) model (Senay, 2018).

The present study combined ground-based evapotranspiration measurements at the study site with remotely sensed evapotranspiration. This approach provides detailed estimates of evapotranspiration combined with onsite measurements for assessing the remote-sensing evapotranspiration data.

\section{Purpose and Scope}

The purpose of this report is to document the effects of huisache removal on evapotranspiration rates at two sites within a rangeland area in Victoria County, Tex., during March 2015-August 2018. The eddy-covariance (EC) and 
remote-sensing methods used to measure evapotranspiration are described. Differences in evapotranspiration measurements made at the two sites (one predominantly grassland and the other dominated by dense huisache that was removed in January 2017, approximately halfway through the study period) are presented, and the spatial and temporal effects of huisache removal on evapotranspiration are evaluated.

\section{Description of Study Area}

The study area is on private ranchland in Victoria County, Tex., about 24 kilometers south of Victoria, Tex. (fig. 1). Long-term average annual rainfall for the area, as calculated from the 1962-2018 annual rainfall record at the National Weather Service (NWS) station at Victoria Regional Airport, Tex. (fig. 1), is 997 millimeters per year ( $\mathrm{mm} / \mathrm{yr}$ ) (table 1). Annual rainfall is highly variable, ranging from 332 millimeters (mm) (2011) to 1,870 mm (2004) (National Oceanic and Atmospheric Administration, 2019). Rainfall during each year of the study was approximately the same as or greater than the long-term average (table 1). The average monthly temperature in the study area (measured at Victoria Regional Airport, 1962-2018) ranges from 53.7 degrees Fahrenheit $\left({ }^{\circ} \mathrm{F}\right)$ in January to $84.6^{\circ} \mathrm{F}$ in August (National Oceanic and Atmospheric Administration, 2019). Two evapotranspiration measurement sites, USGS station number 283534097002100 and USGS station number 283526096594800 , hereinafter referred to as the "grassland site" and the "huisache site," respectively, were established on the private ranch in March 2015 (fig. 1, table 2).

Table 1. Annual (2015-18) and long-term average annual (1962-2018) rainfall at Victoria Regional Airport, Texas.

\begin{tabular}{lccccc}
\hline & $\mathbf{2 0 1 5}$ & $\mathbf{2 0 1 6}$ & $\mathbf{2 0 1 7}$ & $\mathbf{2 0 1 8}$ & $\begin{array}{c}\mathbf{1 9 6 2 -} \\
\mathbf{2 0 1 8}\end{array}$ \\
\hline $\begin{array}{l}\text { Annual and period } \\
\text { rainfall (millimeters } \\
\text { per year) }\end{array}$ & 1,360 & 997 & 1,180 & 1,100 & 997 \\
\hline
\end{tabular}

The study area is relatively flat (less than 1 percent slopes), and soils are sandy loam and clay loam (Natural Resources Conservation Service, 2019). The grassland site includes somewhat poorly drained Edna fine sandy loam soils and moderately well drained Fadden sandy loam soils (Natural Resources Conservation Service, 2019). The huisache site includes Edna fine sandy loam soils and moderately well drained Dacosta-Contee clay loam soils (Natural Resources Conservation Service, 2019). Because of low slope and some areas with somewhat poor drainage, soils in the study area can remain wet for parts of the year after periods of excessive rainfall. The depth to the water table in the study area is greater than 80 inches (Natural Resources Conservation Service, 2019).

The grassland site (USGS station number 283534097002100) was installed in an area dominated by homogenous grass vegetation. The huisache site (USGS station number 283526096594800) was installed in an area dominated by huisache vegetation. The grassland site had a variety of species including Schizachyrium scoparium (little bluestem), Sorghastrum nutans (yellow Indiangrass), and Sporobolus compositus (tall dropseed), which were once dominant across the area (Griffith and others, 2007). The huisache site was dominated by huisache woody vegetation. However, because of fire suppression, overgrazing, and other disturbances, huisache and other woody or thorn-shrub species, including Prosopis glandulosa (honey mesquite), Vachellia rigidula (blackbrush acacia), and Celtis pallida (granjeno), are of concern because they can outcompete grassland species in the region (Griffith and others, 2007).

Figure 2 shows a photograph of the grassland site in March 2015. Figure 3 shows a photograph of the huisache site in March 2015, when the trees were just beginning to leaf out. Figure 4 shows a photograph of the huisache site in August 2016, when the huisache trees were in full leaf out.

Huisache is one of the most formidable woody species for removal in the Texas coastal prairie (Mutz and others, 1978). Its seeds, like those of honey mesquite, have high germination potential immediately upon dissemination, especially if scarified and exposed to temperatures of 26 to 30 degrees

Table 2. Stations providing data for the rangeland evapotranspiration study, Victoria County, Texas, March 2015-August 2018.

[USGS, U.S. Geological Survey; ET, evapotranspiration; NWS, National Weather Service]

\begin{tabular}{|c|c|c|c|c|c|}
\hline $\begin{array}{l}\text { Site identifier } \\
\text { (fig. 1) }\end{array}$ & $\begin{array}{l}\text { Station } \\
\text { number }\end{array}$ & $\begin{array}{l}\text { Station } \\
\text { name }\end{array}$ & Latitude & Longitude & $\begin{array}{l}\text { Type of data } \\
\text { collected }\end{array}$ \\
\hline $\begin{array}{l}\text { USGS grassland } \\
\text { evapotranspiration station }\end{array}$ & 283534097002100 & $\begin{array}{c}\text { ET station (reference site) } \\
\text { near McFaddin, Texas }\end{array}$ & $28^{\circ} 35^{\prime} 37.1^{\prime \prime}$ & $97^{\circ} 00^{\prime} 20.9^{\prime \prime}$ & $\begin{array}{l}\text { Rainfall, eddy-covariance } \\
\text { evapotranspiration }\end{array}$ \\
\hline $\begin{array}{l}\text { USGS huisache } \\
\text { evapotranspiration station }\end{array}$ & 283526096594800 & $\begin{array}{c}\text { ET station (treatment site) } \\
\text { near McFaddin, Texas }\end{array}$ & $28^{\circ} 35^{\prime} 26.5^{\prime \prime}$ & $96^{\circ} 59^{\prime} 48.1^{\prime \prime}$ & $\begin{array}{l}\text { Rainfall, eddy-covariance } \\
\text { evapotranspiration }\end{array}$ \\
\hline $\begin{array}{l}\text { USGS streamflow-gaging } \\
\text { station San Antonio River } \\
\text { near McFaddin, Tex. }\end{array}$ & 08188570 & $\begin{array}{l}\text { San Antonio River near } \\
\text { McFaddin, Texas }\end{array}$ & $28^{\circ} 31^{\prime} 52.5^{\prime \prime}$ & $97^{\circ} 02^{\prime} 33.7^{\prime \prime}$ & Rainfall \\
\hline $\begin{array}{l}\text { NWS station at Victoria } \\
\text { Regional Airport }\end{array}$ & 12912 & Victoria Regional Airport & $28^{\circ} 51^{\prime} 45^{\prime \prime}$ & $96^{\circ} 55^{\prime} 47^{\prime \prime}$ & Rainfall \\
\hline
\end{tabular}




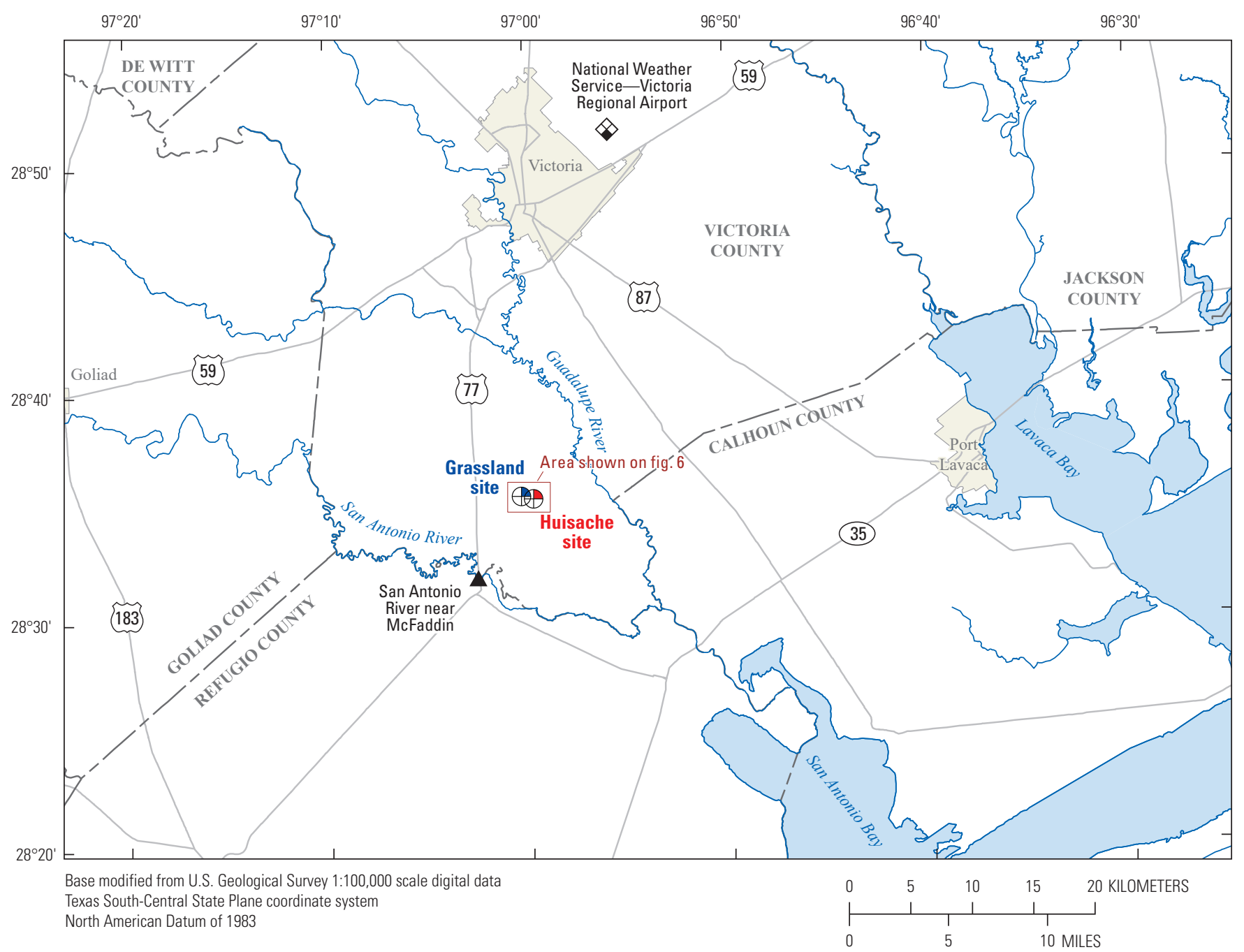

\section{EXPLANATION}
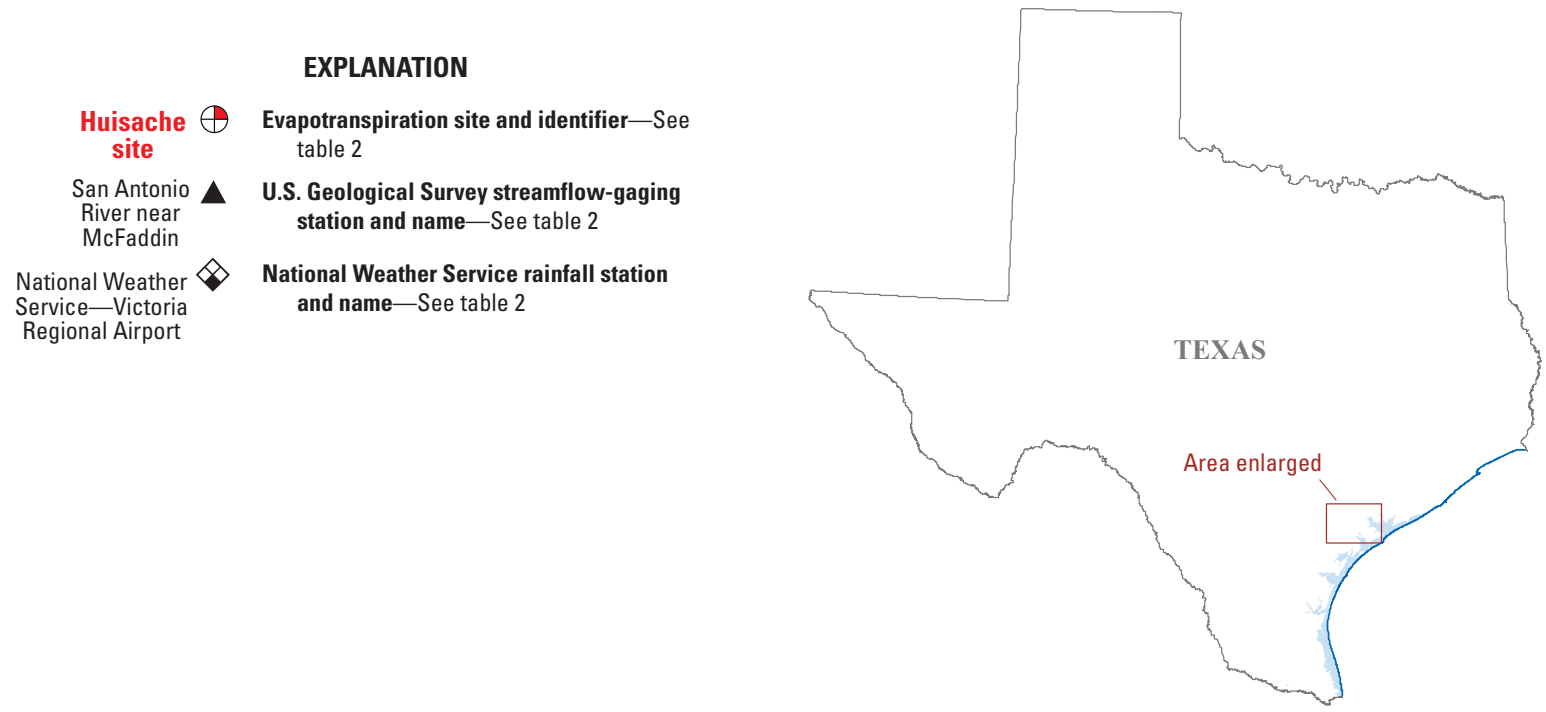

Figure 1. Locations of evapotranspiration monitoring sites and other data-collection stations providing data that were used in the study, Victoria County, Texas. 


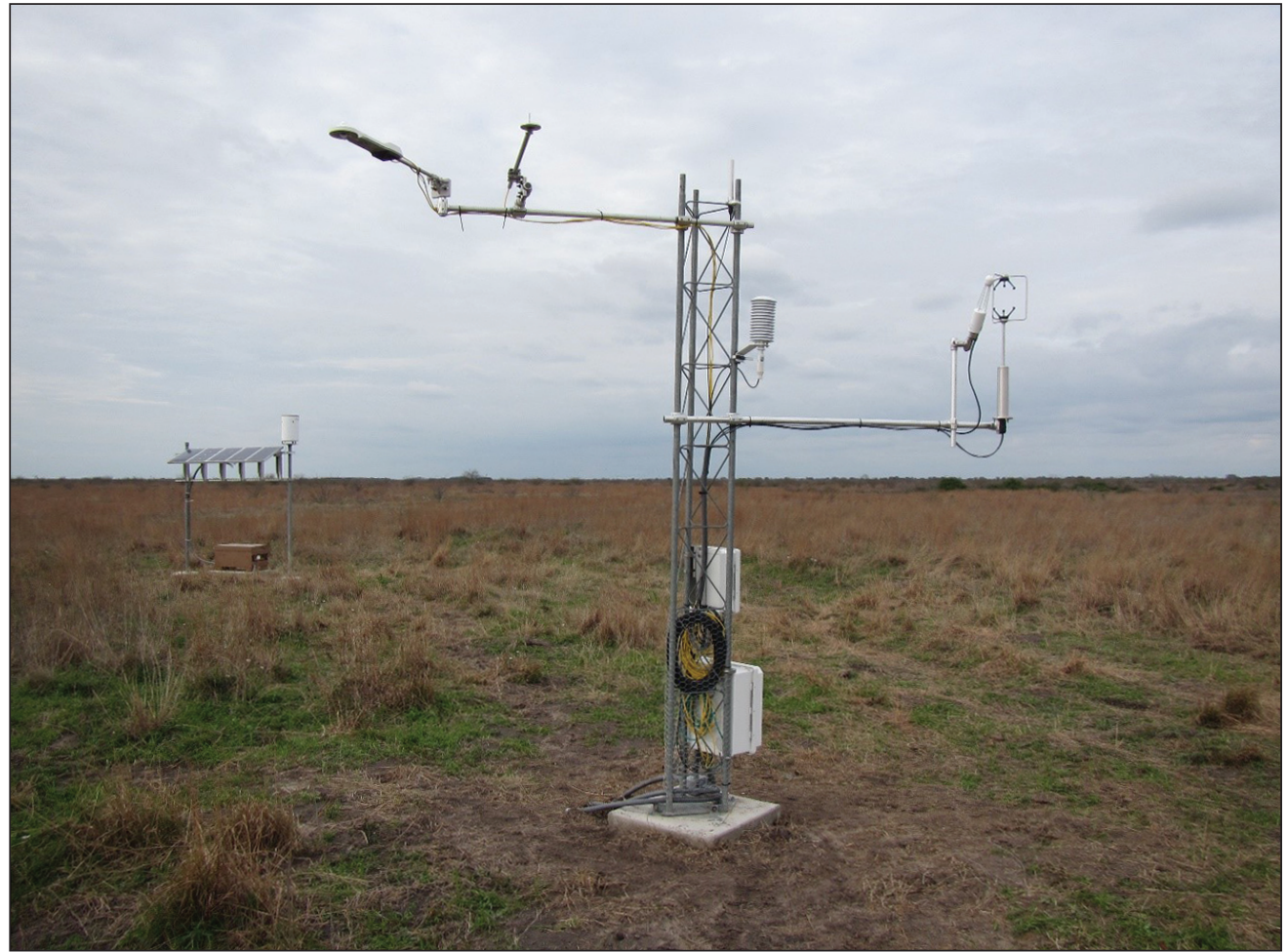

Figure 2. Landscape surrounding the instrument tower at the grassland site evapotranspiration station, Victoria County, Texas, March 2015.

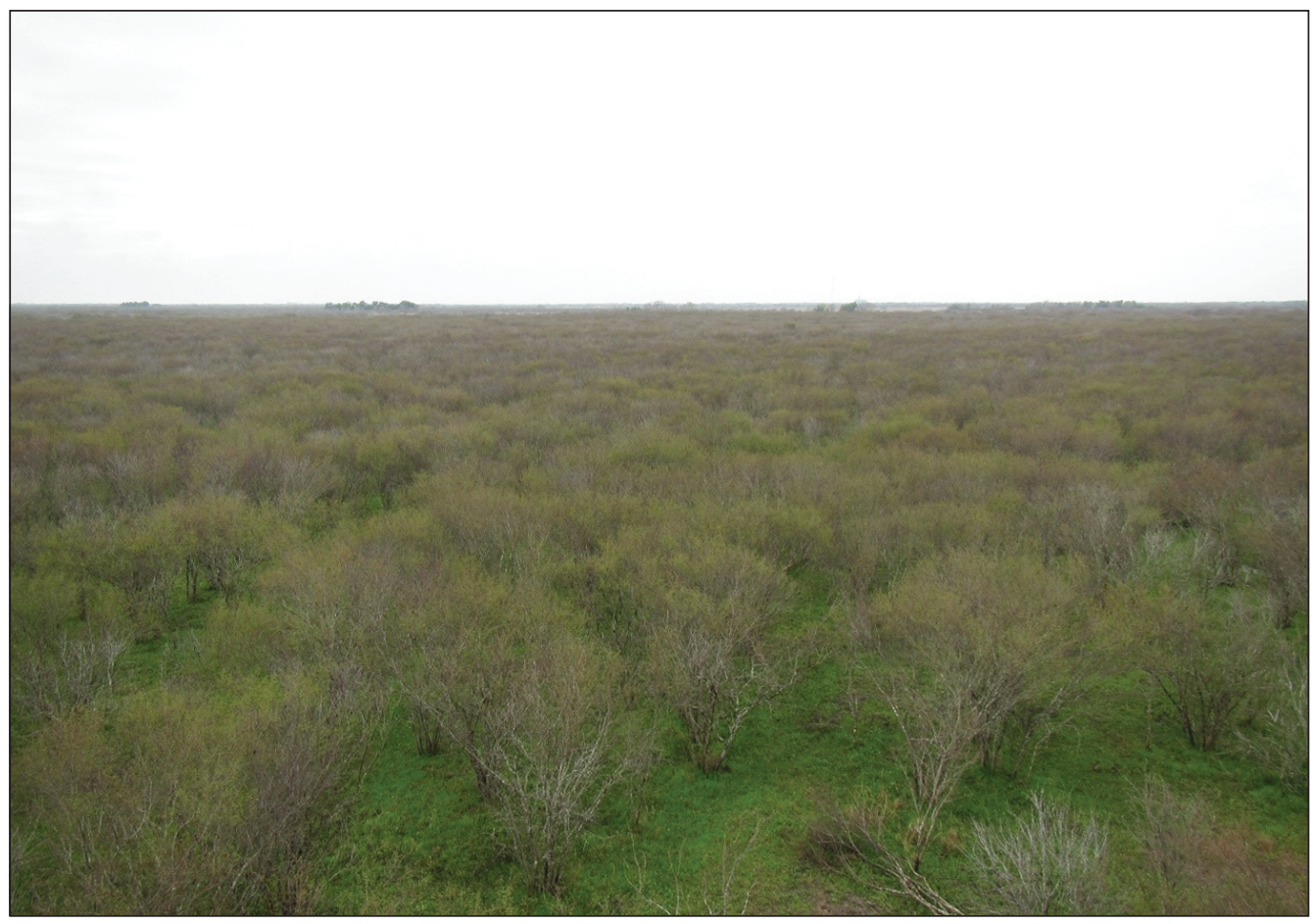

Figure 3. Landscape beginning to leaf out at the huisache site evapotranspiration station, Victoria County, Texas, March 2015 (photograph taken from near the top of the instrument tower). 


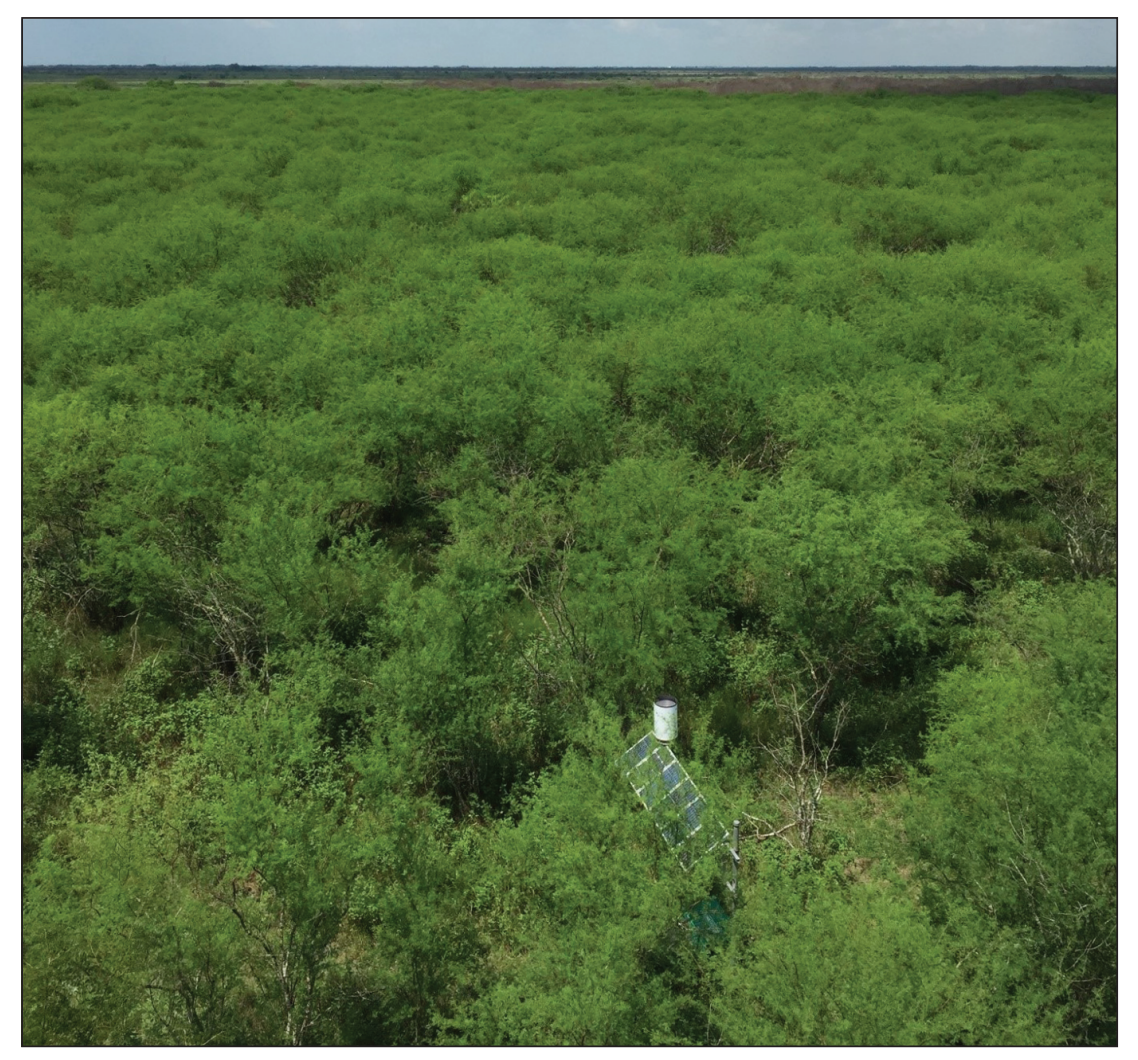

Figure 4. Landscape in full leaf out surrounding the huisache site evapotranspiration station, Victoria County, Texas, August 2016 (photograph taken from near the top of the instrument tower).

Celsius (Scifres, 1974). Once established, the seedlings grow rapidly; they can also resprout readily following damage or top removal. In addition, huisache sprouts can grow to almost half their original total plant height within 5 months after shredding (Powell and others, 1972). Thus, mechanical top removal results in only short-term suppression of huisache (Mutz and others, 1978) and gives the species competitive advantage over associated, slower growing woody plants. Almost pure, dense stands of huisache may develop within two to three growing seasons following brush control methods that disturb the soil (Bontrager and others, 1979).

In January 2017, huisache was removed at the huisache site. The huisache removal was accomplished by uprooting the entire trees and roots with a bulldozer-mounted device that pulled the huisache tree and roots from the ground. The brush was then hauled away from the site. This huisache removal method ensured that the woody plant would not resprout during the study. Figure 5 shows a photograph of the area surrounding the instrument tower at the huisache site in February 2017, after huisache removal. In figure 6 (satellite imagery of study area on March 25, 2017), the extent of huisache removal can be seen as the gray area, extending about $150 \mathrm{~m}$ radially from the instrument tower. After huisache removal, native grasses quickly became established, as seen in the April 2017 photograph taken about 3 months after huisache removal (fig. 7). No seeding of the site was required.

\section{Data-Collection Methods}

Evapotranspiration and rainfall data were collected for the grassland and huisache sites during March 2015-August 2018 (table 2). To measure evapotranspiration by the EC method, the grassland and huisache sites were equipped with the following instrumentation: an open path gas analyzer to measure atmospheric water concentrations, a three-dimensional sonic anemometer to measure wind speed and direction, a net radiometer to measure longwave and shortwave radiation, air temperature and humidity sensors, soil heat flux plates, and soil temperature and soil moisture sensors (table 3 ). Rainfall data were collected at each site with tipping-bucket rain gages and augmented with rainfall data from two nearby stations as needed during periods of missing rainfall data.

\section{Rainfall}

Rainfall was measured in inches at each site (Slattery, 2020) with a NovaLynx 12-inch tipping-bucket rain gage (table 3 ) mounted $2.4 \mathrm{~m}$ above the land surface; for analysis purposes, rainfall data were converted from inches to millimeters. To maintain the accuracy of the rain gages, the instruments were periodically inspected and cleaned, and calibration checks were performed as described 


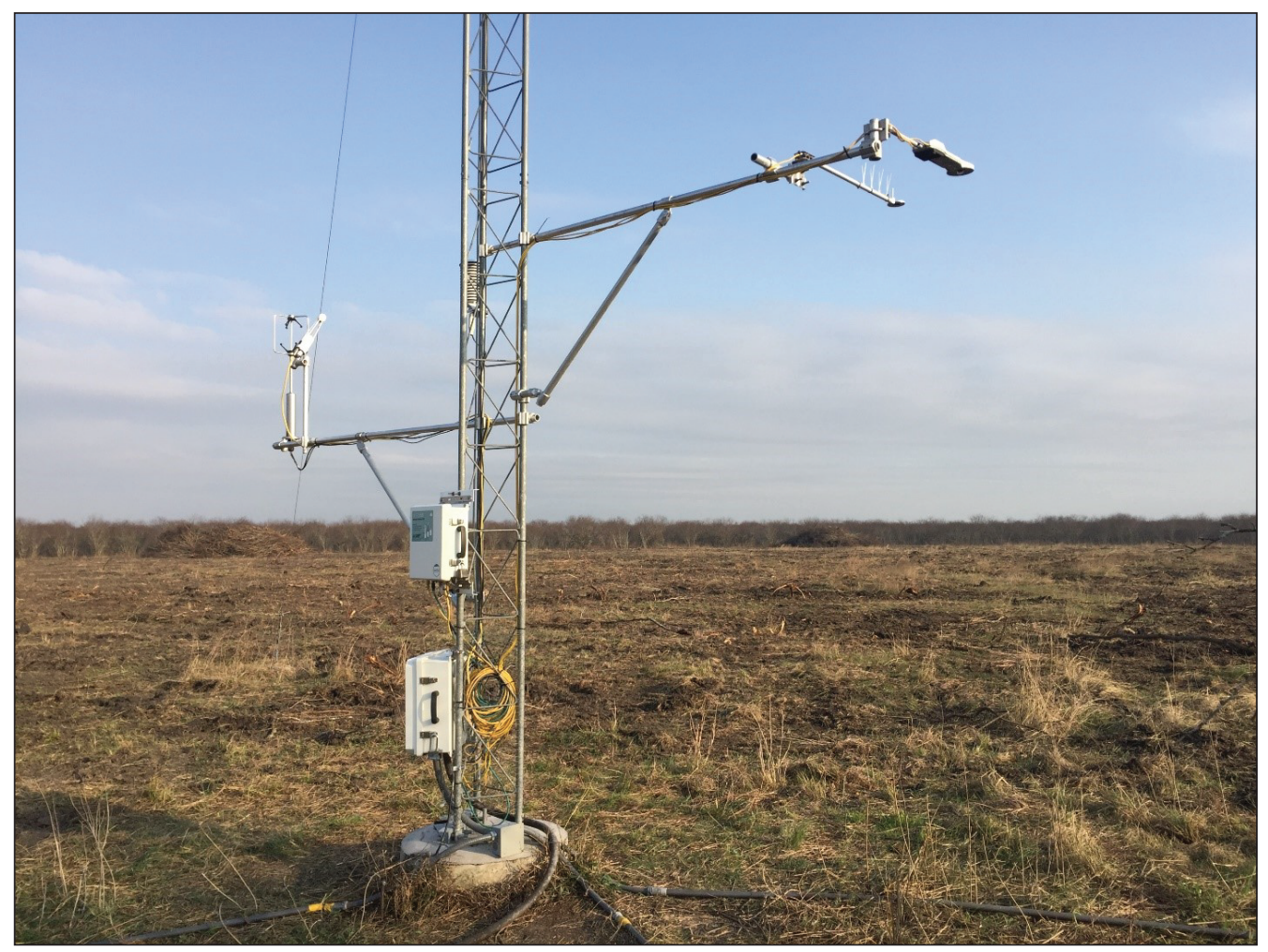

Figure 5. Landscape surrounding the huisache site evapotranspiration station, Victoria County, Texas, on February 2, 2017, after huisache removal.

by the manufacturer and USGS protocols (U.S. Geological Survey, 2005; NovaLynx Corporation, 2019). Instruments not meeting calibration standards (calibration values differed from expected values by more than 8 percent) were replaced. Rainfall data were also reviewed by comparison of data between the two sites to better identify periods when a rain gage might have been clogged and therefore under-recorded rainfall. Affected data were removed from the USGS National Water Information System database (U.S. Geological Survey, 2019b).

Rainfall totals were recorded every 30 minutes, with daily rainfall totals calculated from the sum of the 30-minute values for each day. Daily rainfall totals were not reported for days missing more than 30 percent of the 30 -minute values for a day. Other than removing anomalous values caused by instrumentation noise (anomalous values not corroborated by preceding and subsequent values), no further corrections were made to the rainfall data.

Based on field-calibration checks, the rainfall data are considered accurate to within 8 percent of actual rainfall. The daily rainfall totals at the two sites were highly correlated during 2015-18, with an average site-to-site $\mathrm{R}^{2}$ value (coefficient of determination) (Helsel and Hirsch, 2002) of 0.97 . Given the proximity of the sites and similar physical site conditions (for example, similar slopes and aspects), a representative daily rainfall amount for the study area was developed by averaging the available daily rainfall totals from the two rainfall sites.
For days when measured rainfall data were not available from one of the sites, the measured rainfall at the other site was used as the daily rainfall amount for the study area. For days when rainfall data were not available from either site, daily rainfall was obtained from one of two sources (table 2). The first source was the NWS station at the Victoria Regional Airport. The second source was USGS streamflow-gaging station 08188570 San Antonio River near McFaddin, Tex. (hereinafter referred to as the "McFaddin station"). Compared to the NWS station at the Victoria Regional Airport, the McFaddin station is closer to and likely more representative of rainfall conditions at the evapotranspiration study sites. However, a complete record of daily rainfall for the study period was not available from the McFaddin station. Rainfall data from the McFaddin station were only used to substitute for missing data during extensive rainfall caused by Hurricane Harvey in August-September 2017. A total of 64 days (about 5 percent of the study period) were missing rainfall data from the evapotranspiration sites; those daily values were filled by using a combination of data from the NWS Victoria Regional Airport station and the McFaddin station.

\section{Eddy-Covariance Evapotranspiration}

The process of evapotranspiration consumes energy from the environment, and measuring this transfer of energy is the basis for estimating evapotranspiration (Laczniak and others, 1999). The instrumentation for estimating 


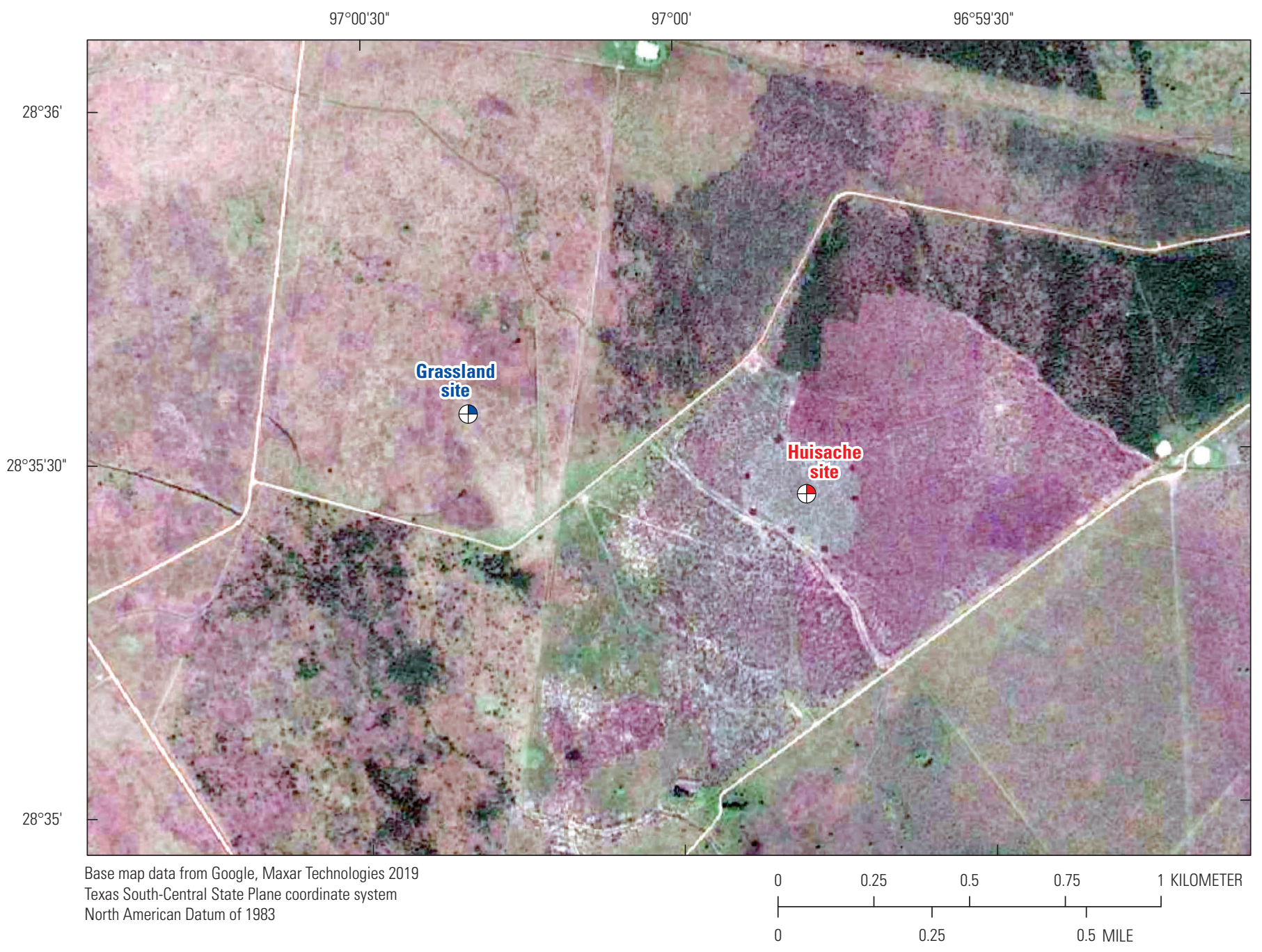

\section{EXPLANATION}

Huisache $\oplus$ Evapotranspiration site and identifier site

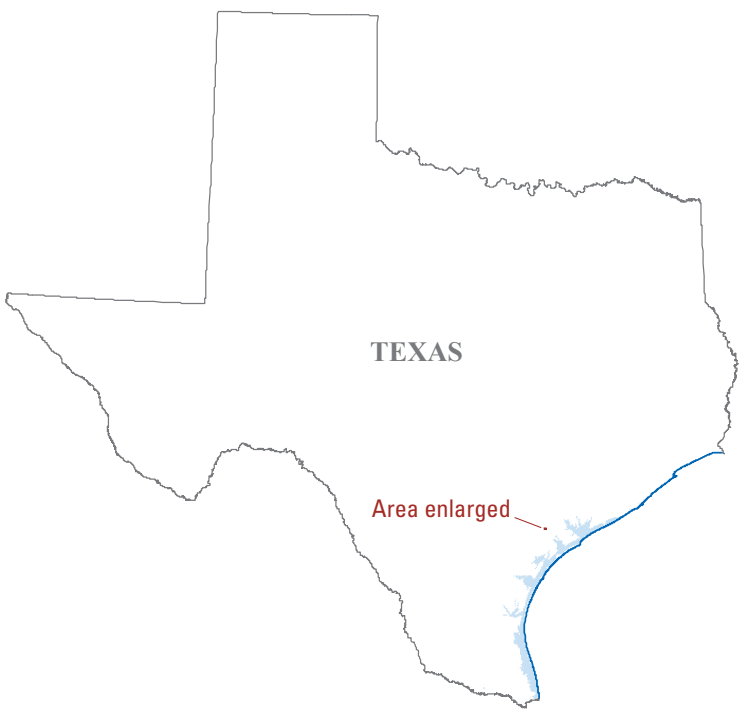

Figure 6. Satellite view of evapotranspiration measurement sites, March 25, 2017, Victoria County, Texas. 


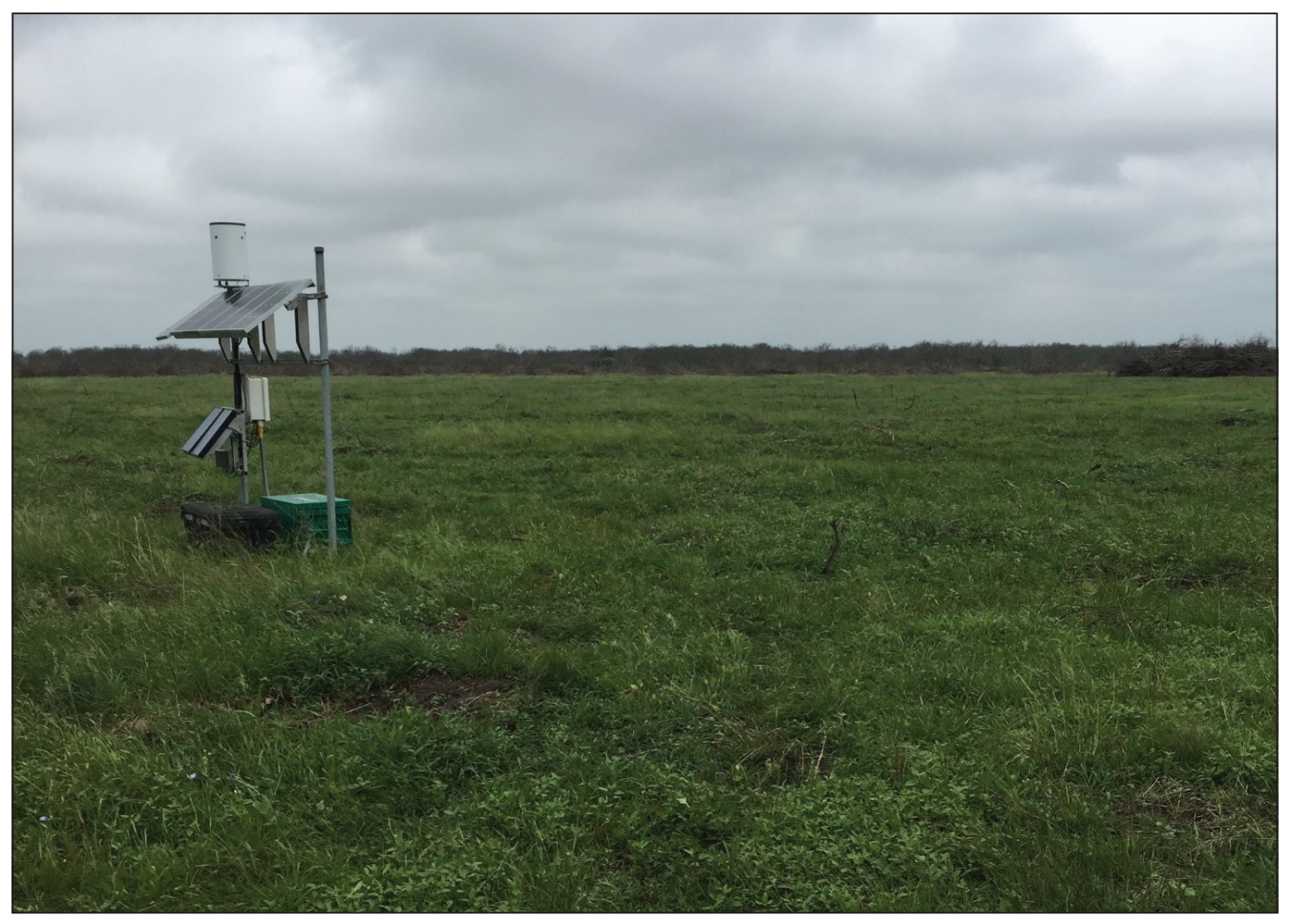

Figure 7. Landscape surrounding the huisache site evapotranspiration station after huisache removal, April 2017, Victoria County, Texas.

evapotranspiration by the EC method measures vertical turbulent fluxes (associated with energy transfer) from the land surface to the atmosphere. These turbulent fluxes are commonly compared to measured radiative fluxes to assess the energy budget.

The energy at Earth's surface can be described by a surface energy budget. Assuming that energy fluxes from other sources and sinks are negligible, the simplified form of the energy budget can be expressed as follows (Brutsaert, 1982):

$$
R_{n}-G-W=L E+H
$$

where

$$
\begin{aligned}
R_{n} & \text { is net radiation, } \\
G & \text { is soil heat flux, } \\
W & \text { represents changes in heat energy stored in the } \\
& \text { vegetation, } \\
L E & \text { is latent-heat flux, and } \\
H & \text { is sensible-heat flux. }
\end{aligned}
$$

All terms in equation 1 are in watts per square meter, and each term is positive during typical daytime conditions. $R_{n}$ is positive when incoming longwave and shortwave radiation exceeds outgoing longwave and shortwave radiation, $G$ is positive when heat moves from the surface into the subsurface, and $W$ is positive when the huisache vegetation gains energy from the sun. $L E$ and $H$ are positive when moving upward from the surface to the atmosphere. The left side of equation 1 $\left(R_{n}-G-W\right)$ represents the available energy for the right side of equation 1; the right side $(L E+H)$ represents the turbulent flux of mass and energy into the atmosphere. For this study, $W$ was considered negligible and was not measured or considered in any calculations.

Turbulent fluxes occur in the lowest layer of the atmosphere, the atmospheric boundary layer, through eddy diffusion. Above a flat, level surface, the average air movement is commonly recognized as being horizontal and is quantified as wind speed. However, superimposed on the average wind is the random turbulent upward and downward movement of wind (eddies), resulting in instantaneous wind vectors with nonzero vertical components. Within an eddy, wind movements are highly correlated and can be quite distinct from those in nearby eddies. Similarly, concentrations of admixtures (for example, the heat, water vapor, or carbon dioxide content) may vary from eddy to eddy. Vertical transport of eddy admixtures results from the vertical components of eddy motions, a process similar to molecular diffusion but on a much larger scale (Brutsaert, 1982; Stannard and others, 2013).

As an eddy moves upward or downward, it carries the admixtures along with it, giving rise to vertical turbulent flux. Above an extensive uniform surface, the net vertical transport of an admixture is equal to the algebraic sum of the transport contributions from all eddies (or a statistically significant sample thereof) passing over the surface (Stannard and others, 2013). Thus, over an evaporating surface, upward-moving eddies contain, on average, more water vapor than do downward-moving eddies. If certain criteria are met, the flux of an admixture can be measured with high-speed measurements (measured at 10 times per second and averaged 
over 30-minute intervals for this study) of vertical eddy motion and the admixture concentration (Stannard and others, 2013). The EC technique provides the most direct measure of turbulent energy flux available (Baldocchi, 2003; Foken and others, 2004; Stannard and others, 2013). Therefore, fluxes of water vapor and heat can be estimated directly without the application of empirical constants (Foken and others, 2004).

In the case of water vapor, the EC equation takes the following form (Dyer, 1961):

$$
L E=\lambda \overline{w^{\prime} \rho^{\prime} v}
$$

where

$$
\begin{aligned}
& L E \quad \text { is the measured latent-heat flux, in watts per } \\
& \text { square meter per day; } \\
& \lambda \quad \text { is the latent heat of vaporization, in joules per } \\
& \text { gram; } \\
& w^{\prime} \quad \text { is the vertical component of wind speed } \\
& \text { and direction, in meters per second; the } \\
& \text { prime symbol denotes deviations from the } \\
& \text { average value over the averaging period } \\
& \text { (upward is positive); and } \\
& \rho^{\prime} \quad \text { is water vapor density, in grams per cubic } \\
& \text { meter; the prime symbol denotes } \\
& \text { deviations from the average value over the } \\
& \text { averaging period. }
\end{aligned}
$$

The quantity $\overline{w^{\prime} \rho_{v}^{\prime}}$ is the covariance of $w^{\prime}$ and $\rho^{\prime} v$; the overbar denotes average value.

The sensible-heat flux is similarly computed, but variations in temperature are considered rather than water vapor:

$$
H=\rho_{a} c_{p} \overline{w^{\prime} T_{a}^{\prime}}
$$

where
$H \quad$ is the measured sensible-heat flux, in watts per square meter;

$\rho_{a} \quad$ is air density, in kilograms per cubic meter;

$c_{p} \quad$ is specific heat of air at constant pressure, in joules per degree Celsius;

$w^{\prime} \quad$ is the vertical component of wind speed and direction, in meters per second; the prime symbol denotes deviations from the average value over the averaging period (upward is positive); and

$T_{a}^{\prime} \quad$ is air temperature, in degrees Celsius; the prime symbol denotes deviations from the average value over the averaging period.

The quantity $\overline{w^{\prime} T^{\prime}}{ }_{a}$ is the covariance of $w^{\prime}$ and $T_{a}^{\prime}$; the overbar denotes average value.

In addition to turbulent flux of heat and mass between the surface and atmosphere, a turbulent flux of horizontal momentum also occurs from the atmosphere to the land surface (Stannard and others, 2013). Horizontal wind speed is zero at the land surface and increases with height above the land surface - a wind-speed profile that indicates greater momentum at height, decreasing to zero momentum at the land surface. This gradient implies a flux of horizontal momentum from the upper atmosphere downward to the land surface, also recognized as a drag force exerted on the surface by the air. The transfer of momentum downward occurs through eddy diffusion and can be expressed as

$$
\tau_{m}=-\rho_{a} \overline{w^{\prime} u^{\prime}}
$$

where

$\tau_{m} \quad$ is the calculated momentum flux or drag per unit area of land surface, in kilograms per meter per second squared;

$\rho_{a} \quad$ is air density, in kilograms per cubic meter; $w^{\prime} \quad$ is the vertical component of wind speed, in meters per second; the prime symbol denotes deviation from the average value (upward is positive); and

$u^{\prime} \quad$ is the horizontal component of wind speed, in meters per second; the prime symbol denotes deviations from the average value. The quantity $\overline{w^{\prime} u^{\prime}}$ is the covariance of $w$ and $u$; the overbar denotes average value. $\tau_{m}$ is calculated concurrently with $L E$ and $H$ (eq. 2 and eq. 3 ) and is used to calculate corrections to those fluxes.

The relation between a given evapotranspiration rate and the associated latent-heat flux is

$$
E T=L E /\left(\rho_{w} \times \lambda\right)
$$

where

ET is evapotranspiration, in millimeters per day;

$L E \quad$ is the latent-heat flux, in watts per square meter;

$\rho_{w} \quad$ is density of water, in kilograms per cubic meter; and

$\lambda$ is the latent heat of vaporization, in joules per kilogram.

Both $\rho_{w}$ and $\lambda$ are very weak functions of temperature, and they are roughly constant over the range of temperatures recorded in this study. Therefore, to express ET as a function of $L E$, equation 5 can be simplified and rewritten approximately as

$$
E T=0.035 \times L E
$$

where

$$
\begin{gathered}
\text { ET is evapotranspiration, in millimeters per day; } \\
L E \quad \text { is the latent-heat flux, in watts per square } \\
\text { meter; and } \\
0.035 \text { is a factor that converts the energy } \\
\text { transfer of the latent-heat flux into an } \\
\text { evapotranspiration rate of water in } \\
\text { millimeters per day. }
\end{gathered}
$$




\section{Instrumentation}

To obtain the meteorological and surface energy flux data needed for the calculation of evapotranspiration, the two sites were instrumented with the LI-COR Biosciences EC system (table 3). Each EC system included an LI-7500A open path gas analyzer with an LI-7550 interface unit to measure atmospheric water concentrations (LI-COR Biosciences, 2019a) and a Campbell Scientific CSAT3 or Gill WindMaster Pro three-dimensional sonic anemometer to measure wind speed and direction and sonic temperature (Campbell Scientific, Inc., 2019; Gill Instruments, 2019). These measurements were made and recorded by the LI-COR LI-7550 at a rate of 10 measurements per second (10 hertz [Hz]). Each EC system also included a LI-COR Biomet system (LI-COR Biosciences, 2016), composed of a Sutron 9210 data logger (Sutron Corporation, 2019); a Kipp \& Zonen CNR4 net radiometer (Kipp \& Zonen, 2019) to measure incoming and reflected solar radiation in both longwave and shortwave bands; a Vaisala HMP155 humidity and temperature probe (Vaisala, 2019); three Hukseflux HFP01 soil heat flux plates (Hukseflux Thermal Sensors, 2016); three LI-COR 7900-180 soil temperature sensors (LI-COR Biosciences, 2019b); three Decagon ECH20 EC-5 soil moisture sensors (Decagon Devices, 2019); and a NovaLynx 12-inch tipping bucket rain gage (NovaLynx Corporation, 2019). The LI-COR Biomet instruments measured data every 5 seconds; these data were averaged or summed (rainfall only) and recorded by the Sutron data logger every minute. The EC system also included a SMARTFlux system module to process raw EC data (.ghg format files which are LICOR Bioscience custom raw file type), computing fully corrected atmospheric fluxes of water vapor and energy by using the EddyPro software version 6.2 (LICOR Biosciences, 2016).

The gas analyzer, sonic anemometer, radiometer, and humidity and temperature sensor at the grassland site were mounted on a 3-m tower at $2.6 \mathrm{~m}$ above the land surface and over a vegetation height of approximately $0.6 \mathrm{~m}$.

The gas analyzer, sonic anemometer, radiometer, and humidity and temperature sensor at the huisache site were mounted on a $12-\mathrm{m}$ tower at $8.4 \mathrm{~m}$ above the land surface and over a huisache canopy approximately $4.5 \mathrm{~m}$ in height. After the removal of huisache in January 2017, these instruments at the huisache site were lowered to a height of $2.8 \mathrm{~m}$ above the land surface and over existing vegetation with a canopy height of about $0.6 \mathrm{~m}$.

At the grassland site, the three sets of soil heat flux plates, soil moisture sensors, and soil temperature sensors were placed at locations within $10 \mathrm{~m}$ of the tower. At the huisache site, the three sets of soil heat flux plates, soil moisture sensors, and soil temperature sensors were placed at different locations with varied amount of sun and shade. At both sites, the ground sensors were buried at depths approximately 5 centimeters $(\mathrm{cm})$ below the land surface. The calibration of the soil moisture sensors was verified by using soil moisture data collected from near the location of the ground sensors. Soil cores with a diameter of approximately $2 \mathrm{~cm}$ and a length of about $8-10 \mathrm{~cm}$ were collected using a straight barrel sampler and then sealed in a glass container. The soil cores were then transported to the USGS Oklahoma-Texas

Table 3. Instruments used to measure evapotranspiration, energy balance, and rainfall at eddy-covariance evapotranspiration sites, Victoria County, Texas.

\begin{tabular}{|c|c|c|c|}
\hline Type of measurement & Manufacturer & $\begin{array}{l}\text { Model number and } \\
\text { instrument type }\end{array}$ & Source \\
\hline $\begin{array}{l}\text { Evapotranspiration (water vapor } \\
\text { concentration) }\end{array}$ & LI-COR Biosciences & LI-7500A open path gas analyzer & LI-COR Biosciences, 2019a \\
\hline $\begin{array}{l}\text { Evapotranspiration (turbulent } \\
\text { fluctuations of horizontal and } \\
\text { vertical wind) }\end{array}$ & $\begin{array}{l}\text { Campbell Scientific, Inc., or } \\
\text { Gill Instruments }\end{array}$ & $\begin{array}{l}\text { CSAT3 three-dimensional sonic } \\
\text { anemometer or WindMaster Pro } \\
\text { sonic anemometer }\end{array}$ & $\begin{array}{l}\text { Gill Instruments, 2019; Campbell } \\
\text { Scientific, Inc., } 2019\end{array}$ \\
\hline Net radiation & Kipp \& Zonen & CNR4 net radiometer & Kipp \& Zonen, 2019 \\
\hline Soil temperature & LI-COR Biosciences & $\begin{array}{l}\text { Three } 7900-180 \text { soil temperature } \\
\text { sensors }\end{array}$ & LI-COR Biosciences, 2019b \\
\hline Soil moisture & Decagon Devices & $\begin{array}{l}\text { Three ECH20 EC-5 soil moisture } \\
\text { sensors }\end{array}$ & Decagon Devices, 2019 \\
\hline Data processer and software & LI-COR Biosciences & $\begin{array}{l}\text { SmartFlux system and EddyPro } \\
\text { software, version } 6.2\end{array}$ & LI-COR Biosciences, 2016 \\
\hline Data logger & Sutron Corporation & 9210 data logger & Sutron Corporation, 2019 \\
\hline
\end{tabular}


Water Science Center office in San Antonio, Tex., where they were weighed, oven dried for 24 hours, reweighed, and soil moisture calculated and compared with the measured sensor data (Burt, 2014).

The sites were visited periodically for maintenance and repairs. During the visits, the lenses of the radiometers and gas analyzers were inspected, cleaned, and rinsed with deionized water. At least annually, the gas analyzers were returned to LI-COR Biosciences for recalibration. Other sensors such as the humidity and temperature sensors and the soil sensors were checked to ensure operation and replaced if needed.

\section{Data Processing}

Evapotranspiration-related data collected by the various sensors were merged into self-contained, compressed .ghg files every half hour and were processed with the LI-COR SmartFlux module and LI-COR EddyPro software, version 6.2 (LI-COR Biosciences, 2016). To operate correctly and to produce valid EC datasets, site-specific variables were entered into the LI-7500 SmartFlux module by using the LI-COR Greenhouse Gas (GHG) software interface. These variables included the height of the gas analyzer and sonic anemometer above the land surface, height of the vegetation canopy around the site, displacement distance of the gas analyzer relative to the sonic anemometer, and the sonic anemometer orientation from magnetic north. On the half hour, the EddyPro software would process the half hour of $10-\mathrm{Hz}$.ghg files into a 30-minute average. At the end of the day, the files were merged into a single file containing the 30 -minute averages for the previous 24 hours. The $10-\mathrm{Hz}$.ghg files, 30-minute EddyPro outputs, and the daily summary files were recorded to a universal serial bus (USB) drive for storage. At the end of each day, an office computer running the LI-COR file transfer program would connect with the LI-7500 system, through a cellular modem, and download the recorded file. EddyPro software was then used to reprocess the raw $10-\mathrm{Hz}$ EC data (.ghg files) and to compute fully corrected water vapor and energy fluxes.

To improve flux measurements, the EddyPro software applies several corrections and statistical tests to correct or filter the raw $10-\mathrm{Hz}$ EC flux data. These corrections and tests include tilt correction (Wilczak and others, 2001), extracting turbulent fluctuations from time-series data (Gash and Culf, 1996), and compensation for possible time lags between anemometric variables and variables measured by the gas analyzer (Fan and others, 1990).

Soil heat flux $(G)$ is calculated by using measurements obtained from the soil heat flux plates, soil temperature sensors, and soil moisture sensors buried near the tower. Three soil heat flux plates were buried at a depth of about $5 \mathrm{~cm}$ where the overlying soil is exposed to varying amounts of shade and sun. Soil moisture sensors measure the volumetric water content of the soil. The change in heat stored in the soil solids and soil water above the soil heat flux plates was added to the heat flux measured by the soil heat flux plates to obtain $G$ (Campbell Scientific, Inc., 2016). A single value of $G$ was estimated by averaging the three Hukseflux HFP01 soil heat flux estimates that included heat storage above the plates. Heat storage above each plate was calculated from measurements of soil bulk density, organic content, and soil temperature and volumetric soil moisture by using the calorimetric method (Liebethal and others, 2005). Soil temperature was measured by averaging the data from the three LI-COR 7900-180 soil temperature sensors. Soil moisture was measured by averaging the data from the three Decagon ECH20 EC-5 soil moisture sensors.

\section{Quality Assurance of Energy Flux and Meteorological Data}

Review of the measured energy flux data included net radiation $\left(R_{n}\right)$, latent-heat flux $(L E)$, sensible-heat flux $(H)$, and $G$. Some loss of data occurred as a result of station power loss. Edits were also made to the data during site visits, primarily removal from the data file of erroneous sensor readings that could occur during instrument service and cleaning.

The 30-minute measurements of $L E$ and $H$ processed by the EddyPro software included a data quality "flag" based on Mauder and Foken (2006). Data-quality flag values of 0 , 1 , or 2 were assigned, with a value of 0 indicating a measurement of high quality, a value of 1 indicating a measurement suitable for energy-budget analysis, and a value of 2 indicating a measurement of possible poor quality that should be reviewed and possibly not used. If a data-quality flag value was 2 , the 30-minute $L E$ and $H$ flux data were generally deleted. $L E$ and $H$ data were also reviewed for outliers by following recommendations of the AmeriFlux network for data archiving (Law and others, 2005) and by comparing data from the two sites. Acceptable thresholds for both $L E$ and $H$ were set to between 675 and -50 watts per square meter $\left(\mathrm{W} / \mathrm{m}^{2}\right)$ for daytime and between 75 and $-75 \mathrm{~W} / \mathrm{m}^{2}$ for nighttime. Values above or below these thresholds were discarded. $L E$ and $H$ were also inspected, and values considered spurious were rejected. Data that were rejected by using this approach were typically values measured during periods of rainfall or condensation.

Meteorological data, including air temperature, air pressure, water vapor density, water vapor partial pressure, specific humidity, relative humidity, wind speed, and wind direction, also were reviewed to identify missing data or potentially spurious values (identified as individual, or a few values that were greater than 50 percent different from adjacent values when values at the other site did not exhibit the same trend). For missing, or potentially spurious, data intervals of less than 3 hours, the missing 30-minute values were replaced with linearly interpolated values, interpolated between the value immediately preceding and immediately following the problematic data interval. Missing data intervals of greater than 3 hours were not filled. 


\section{Source Area of Measurements}

The source area for EC turbulent-flux measurements is the dynamic upwind land-surface area contributing to measured water vapor and heat fluxes, whereas source areas for available-energy measurements are constant and depend on instrument placement. Thus, turbulent-flux source areas are larger and more variable than available-energy source areas (Garcia and others, 2015).

The area surrounding the EC stations that influences the measurements is referred to as the "fetch footprint" of the study sites. The fetch footprint is the area "seen" by the instruments on the tower, such that the water fluxes generated in this area are registered, or measured, by the tower instruments. Fetch is often reported as a distance from the tower when describing the footprint. The fetch also describes the land features such as ground cover, vegetation types, water bodies, and structures that influence airflow patterns and thus affect measured fluxes (Burba, 2013).

The area of the flux footprint of each of the sites was estimated by using the EddyPro software with one of two flux models built into this software, either the Kljun model (Kljun and others, 2004) or the Kormann and Meixner model (Kormann and Meixner, 2001). The EddyPro software uses the Kljun model as the default. When values are outside of predefined ranges of atmospheric conditions of stability and turbulence, the EddyPro software automatically switches to the Kormann and Meixner model. Both models depend on the height of the instruments, height of the vegetation canopy, surface roughness, and stability of the atmosphere.

The EddyPro software output provided an estimate of the measured turbulent-flux footprint as a set of peak distances from the instrument tower, expressed as a percentage $(10,30$, 50,70 , and 90 percent) of contributions to the total fluxes, and from the corresponding wind direction. A plot of the average daytime cumulative turbulent-flux contributions by distance from the instrument tower at each site for the pre- and post-removal periods is shown in figure 8 .

By using the two flux models built into the EddyPro software, it was estimated that 90 percent of the measured atmospheric fluxes at the grassland site during daytime hours originated from within about $200 \mathrm{~m}$ of the instrument tower during the pre-removal period and from within about $150 \mathrm{~m}$ of the tower during the post-removal period (fig. 8); the EddyPro software provides a confidence interval of 95 percent for each of these estimates. For the huisache site, it was estimated that 90 percent of the measured atmospheric fluxes originated from within $250 \mathrm{~m}$ of the instrument tower during the pre-removal period and within $200 \mathrm{~m}$ during the post-removal period, also at a confidence interval of 95 percent (fig. 8). During the pre-removal period, the vegetation within $250 \mathrm{~m}$ of the tower at each site was uniform grasses or huisache, respectively, and thus the fetch was considered to appropriately represent the grassland and huisache-dominated sites. During the post-removal period, the fetch at the huisache site appropriately represented an area where huisache had been removed.

\section{Evapotranspiration Data}

The 30-minute eddy-covariance evapotranspiration $\left(\mathrm{ET}_{\mathrm{EC}}\right)$ data were reviewed in several steps. If the $L E$ value was discarded, the $\mathrm{ET}_{\mathrm{EC}}$ value also was discarded. For data gaps of less than 3 hours, the missing 30-minute $\mathrm{ET}_{\mathrm{EC}}$ values were replaced with values interpolated between the $\mathrm{ET}_{\mathrm{EC}}$

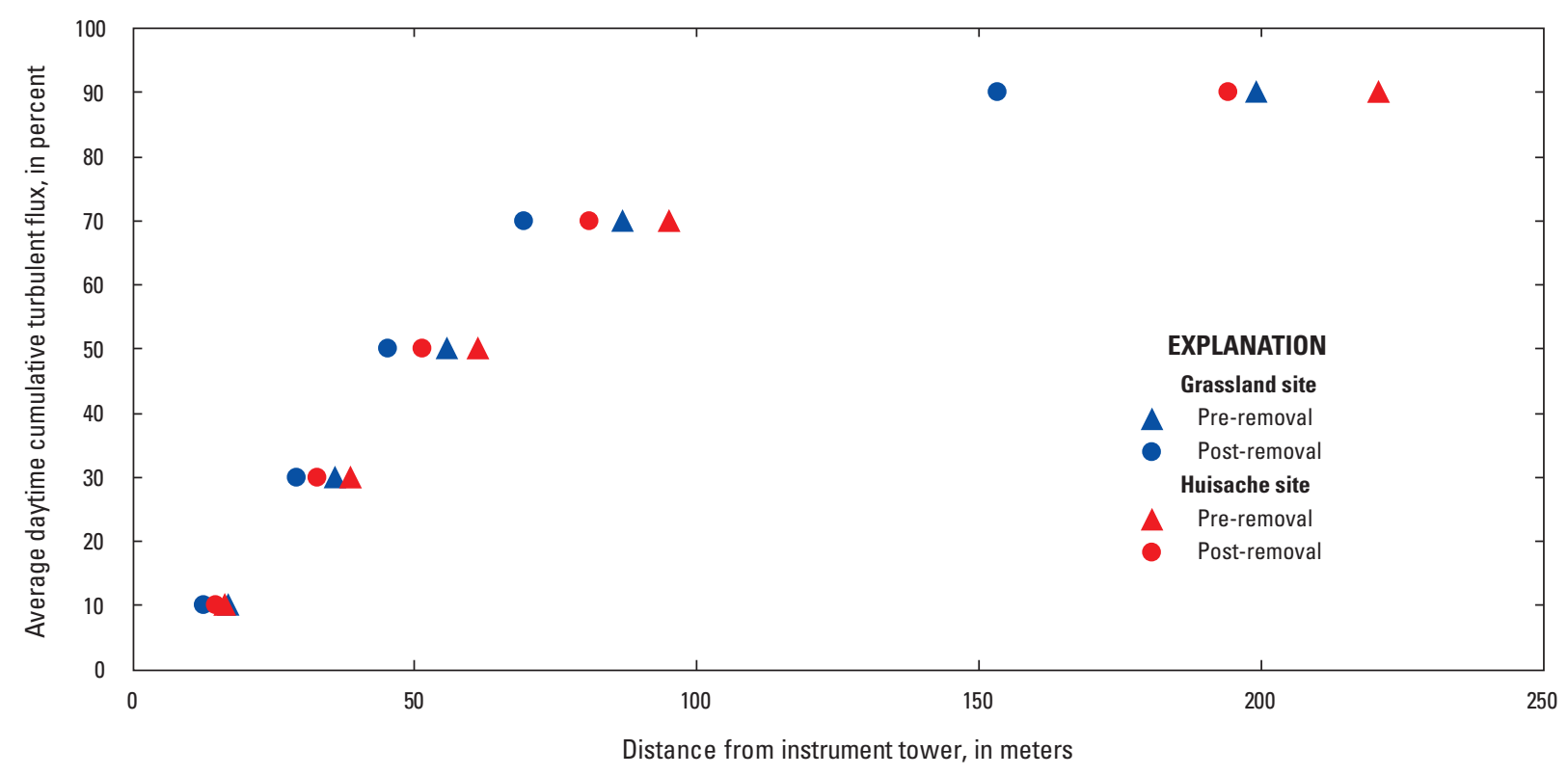

Figure 8. Source-area contributions of average daytime cumulative turbulent flux (expressed as percentages of $10,30,50,70$, or 90 ) for the grassland and huisache evapotranspiration sites, Victoria County, Texas, before (pre-removal, March 2015-December 2016) and after (post-removal, February 2017-August 2018) huisache removal. 
value immediately preceding and the $\mathrm{ET}_{\mathrm{EC}}$ value immediately following the data gap. For data gaps of 3 hours or more occurring at night, missing values were set to zero. For data gaps of 3 hours or more occurring in daytime and during periods of rainfall, a time interval was selected at the peak of the rain event or in the middle of the rain event and set to zero; remaining missing values were then replaced with interpolated values.

Daily $\mathrm{ET}_{\mathrm{EC}}$ values were totaled from the 30 -minute $\mathrm{ET}_{\mathrm{EC}}$ values for a 24-hour period. The daily total included $\mathrm{ET}_{\mathrm{EC}}$ values that were estimated as described earlier. However, daily totals were not reported if more than 30 percent of the 30-minute $\mathrm{ET}_{\mathrm{EC}}$ values measured during the daytime period were missing or estimated. Daily $\mathrm{ET}_{\mathrm{EC}}$ totals were available for the grassland site from March 14, 2015, to August 31, 2018. Daily $\mathrm{ET}_{\mathrm{EC}}$ totals were available for the huisache site from March 13, 2015, to August 22, 2018.

Table 4 summarizes the number of daily $\mathrm{ET}_{\mathrm{EC}}$ values collected at each site and also the number of days for which concurrent daily values were available (number of days where direct comparison of $\mathrm{ET}_{\mathrm{EC}}$ rates between the sites can be made). For the overall data-collection period, the daily-value

Table 4. Number of daily evapotranspiration values collected at the grassland and huisache sites, Victoria County, Texas, March 2015-August 2018.

[ET, evapotranspiration]

\begin{tabular}{lccccc}
\hline & $\mathbf{2 0 1 5}$ & $\mathbf{2 0 1 6}$ & $\mathbf{2 0 1 7}$ & $\mathbf{2 0 1 8}$ & Total \\
\hline $\begin{array}{c}\text { Total daily ET values- } \\
\text { grassland site }\end{array}$ & 274 & 287 & 304 & 232 & 1,097 \\
$\begin{array}{c}\text { Total daily ET values - } \\
\text { huisache site }\end{array}$ & 242 & 284 & 313 & 215 & 1,054 \\
$\begin{array}{l}\text { Days for which daily ET } \\
\text { values were available for } \\
\text { both sites }\end{array}$ & 233 & 253 & 280 & 189 & 955 \\
\hline
\end{tabular}

record is about 86 percent complete for the grassland site and 82 percent complete for the huisache site.

The effects of huisache removal were also evaluated by using estimates of evapotranspiration derived from remote-sensing-based surface energy-balance models (Allen and others, 2007; Senay, 2018). Remote-sensing-based estimates of evapotranspiration complemented station-based estimates of evapotranspiration made by the EC method and provided additional information to evaluate the spatial and temporal effects of huisache removal on evapotranspiration. Missing values were estimated to compare $\mathrm{ET}_{\mathrm{EC}}$ rates between the two sites for the pre-removal and post-removal periods and $\mathrm{ET}_{\mathrm{EC}}$ rates with evapotranspiration determined by remote sensing. The method used to estimate missing daily values is based on a relation between measured evapotranspiration and daily reference evapotranspiration $\left(E T_{r}\right)$, where $E T_{r}$ was computed using the American Society of Civil Engineers standardized reference evapotranspiration equation for a tall reference surface (Allen and others, 2005) and weather data acquired from gridMET (University of Idaho, 2019; Abatzoglou, 2013).

Measured daily $\mathrm{ET}_{\mathrm{EC}}$ values were divided by $E T_{r}$ to calculate the fraction of reference evapotranspiration $\left(E T_{r} F\right)$. This calculated $E T_{r} F$ value was then used in creating a 7-day running average of $E T_{r} F$. Days with missing $\mathrm{ET}_{\mathrm{EC}}$ data were filled by multiplying the daily total $E T_{r}$ by the gap-filled daily $E T_{r} F$ value derived from the 7-day moving average (centered on day 4) of $E T_{r} F$. For gaps in station data greater than or equal to 7 days, the moving average of $E T_{r} F$ was used until the 7-day averaging window no longer contained two valid calculated $E T_{r} F$ values, at which point the remainder of the gap was bridged by linear interpolation. The resulting gap-filled dataset of daily $\mathrm{ET}_{\mathrm{EC}}$ values includes the period March 2015 through August 2018 for both sites. A time series of measured daily $\mathrm{ET}_{\mathrm{EC}}$ values is shown in figure 9.

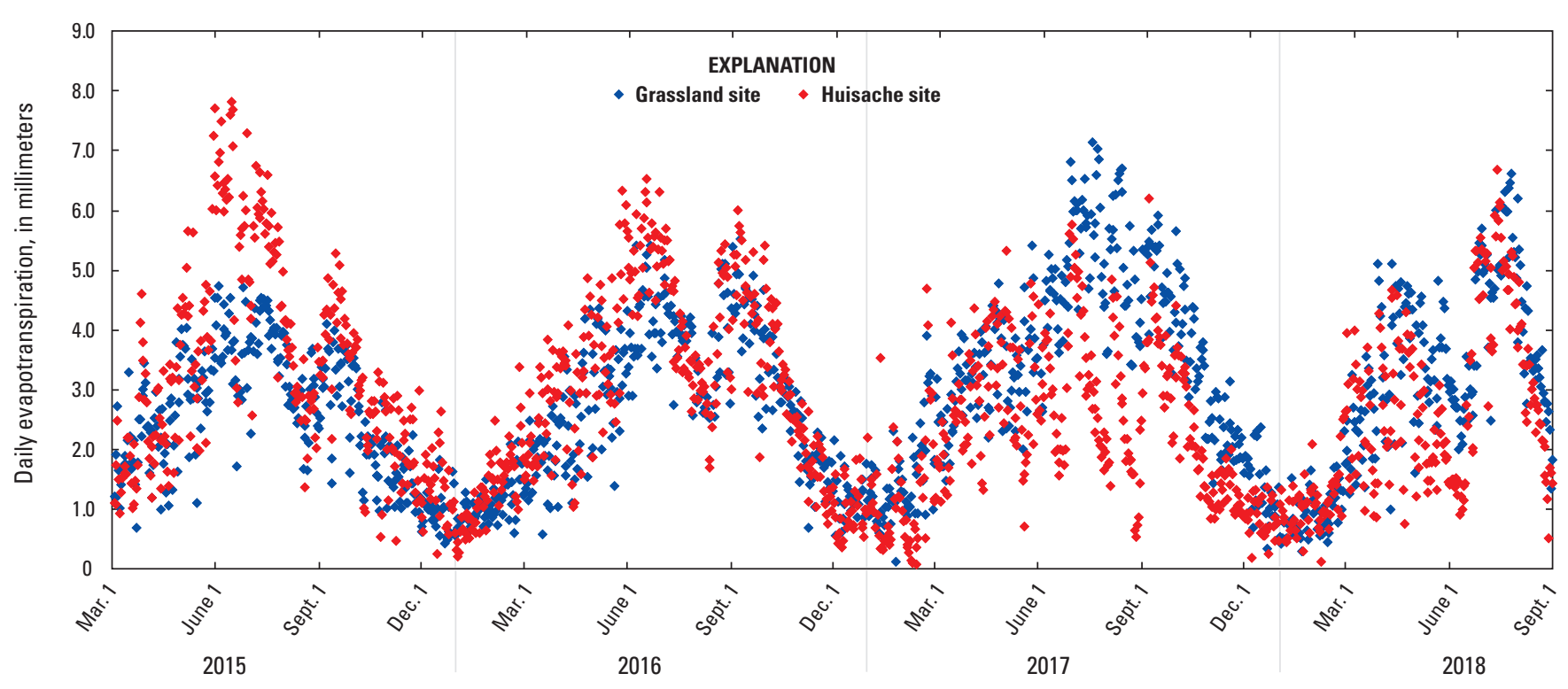

Figure 9. Daily eddy-covariance evapotranspiration values at the grassland and huisache sites, Victoria County, Texas, March 2015-August 2018. 
Daily totals of $\mathrm{ET}_{\mathrm{EC}}$ and daily average values of energy fluxes from the grassland and huisache sites are provided in a USGS data release (Slattery, 2020). The data release also includes 30-minute values of micrometeorological data collected at each station.

\section{Energy-Balance Closure}

Based on the principle of energy conservation, available energy $\left(R_{n}-G\right.$ in eq. 1 ; that is, the net radiation occurring on the landscape minus the soil heat flux and ignoring small changes in the heat stored by the vegetation) is equal to the turbulent flux ( $L E+H$ in eq. 1 ; that is, the latent-heat flux plus the sensible-heat flux). The conservation of energy requires that both sides of equation 1 balance. The simplified left side of equation $1\left(R_{n}-G\right)$ is estimated from measurements of net radiation, soil heat flux, and soil heat storage via measurements of soil temperature and water content, whereas the right side of equation $1(L E+H)$ is estimated by the EC method. The fundamental criterion of the conservation of energy is that the energy balance is satisfied, and therefore the available energy is equal to the turbulent flux. This concept commonly is referred to as "energy-balance closure" (Foken and others, 2012). The energy-balance closure is often evaluated using the energy-balance ratio $(E B R)$, or ratio of the turbulent flux to available energy:

$$
E B R=(L E+H) /\left(R_{n}-G\right)
$$

The $E B R$ at the grassland and huisache sites were computed to assess energy-balance closure of the measurements of available energy $\left(R_{n}-G\right)$ and turbulent fluxes $(L E+H)$. Table 5 summarizes the average energy-balance data and the calculated $E B R$ for the study period.

Ideally, if all energy fluxes are accounted for, measured accurately (within the limits of measurement accuracy), and representative of energy source areas, then the $E B R$ will equal 1 , but studies have shown that EC-derived turbulent fluxes $(L E+H)$ are consistently less than the available energy $\left(R_{n}-G\right)$. Leuning and others (2012) and Foken (2008) studied the results of other investigators and reported $E B R$ values ranging from 0.39 to 1.69 at $22 \mathrm{EC}$ sites. Typical $E B R$ values range from 0.6 to 1.0 , but most frequently range from 0.7 to 0.8 (Moreo and others, 2017). Various theories have been advanced to explain the discrepancy between EC flux and available energy, including (1) lack of coincidence of the source areas among various flux components; (2) flux divergence arising from transport that is not one dimensional such as insufficient fetch; (3) measurement errors related to sensor separation, frequency response, alignment problems, and interference from tower or instrument-mounting structures (Twine and others, 2000); and (4) inaccurate accounting of heat storage (Leuning and others, 2012).

Because knowledge regarding sources of energy-balance discrepancies is limited, the decision of whether to force closure is often subjective (Garcia and others, 2015). For closure adjustments to be accurate, several assumptions are necessary, including (1) available-energy estimates are error free; (2) EC measurements and the application of accepted corrections and filters are accurate; (3) discrepancy between available energy and the turbulent flux can be attributed to turbulent-flux measurements, possibly caused by advective flux divergence with similar scalar ratios to those measured by the EC system; and (4) available-energy estimates are representative of the same source area as EC measurements (Garcia and others, 2015).

For the grassland site, the average $E B R$ was 0.87 during the overall study period (table 5). For the huisache site, the average $E B R$ was 0.93 overall. However, there was some variation in the $E B R$ s during the study, as shown in figure 10.

During various periods of the study, the difference in $E B R$ s between the sites changes. The reasons for these changes in $E B R$ s are not known. Because of these differences in $E B R$ s over time and between sites, measured $\mathrm{ET}_{\mathrm{EC}}$ values at both sites were adjusted with the application of a monthly closure factor to attempt to account for sensor or measurement biases previously described. Although the overall EBRs are similar at each site, the $E B R$ at the grassland site is noticeably higher during 2017 than at the huisache site (fig. 10).

For this study, similar to the approach by Garcia and others (2015), the measured turbulent fluxes were considered a probable minimum. A probable maximum was computed by dividing the monthly $\mathrm{ET}_{\mathrm{EC}}$ by the 3-month moving average $E B R$ (fig. 10). The most probable estimate of the latent-heat (evaporative) flux for this study was considered to be the average of the probable minimum and probable maximum estimates. The most probable estimate is hereinafter referred to as "corrected," and the resulting corrected monthly values of $\mathrm{ET}_{\mathrm{EC}}$ are referred to as "corrected eddy-covariance evapotranspiration" $\left(\mathrm{ET}_{\mathrm{C}}\right)$. Monthly values of $\mathrm{ET}_{\mathrm{C}}$ are available in Slattery (2020).

Table 5. Summary of average energy-balance data and calculated energy-balance ratio at the grassland and huisache evapotranspiration sites, March 2015-August 2018.

$\left[R_{n}\right.$, net radiation; $\mathrm{W} / \mathrm{m}^{2}$, watt per square meter; $G$, soil-heat flux; $L E$, latent-heat flux; $H$, sensible-heat flux; $E B R$, energy-balance ratio]

\begin{tabular}{lccccccc}
\hline & $\begin{array}{c}\boldsymbol{R}_{\boldsymbol{n}} \\
\left(\mathbf{W} / \mathbf{m}^{2}\right)\end{array}$ & $\begin{array}{c}\boldsymbol{G} \\
\left(\mathbf{W} / \mathbf{m}^{2}\right)\end{array}$ & $\begin{array}{c}\text { Available } \\
\mathbf{e n e r g y} \\
\left(\mathbf{W} / \mathbf{m}^{2}\right)\end{array}$ & $\begin{array}{c}\boldsymbol{L E} \\
\left(\mathbf{W} / \mathbf{m}^{2}\right)\end{array}$ & $\begin{array}{c}\boldsymbol{H} \\
\left(\mathbf{W} / \mathbf{m}^{2}\right)\end{array}$ & $\begin{array}{c}\text { Turbulent } \\
\text { flux } \\
\left(\mathbf{W} / \mathbf{m}^{2}\right)\end{array}$ & $\begin{array}{c}\mathbf{E B R} \\
\text { (unitless) }\end{array}$ \\
\hline Grassland site & 164 & 4.8 & 159 & 96.4 & 42.7 & 139 & 0.87 \\
Huisache site & 154 & 1.7 & 152 & 88.6 & 53.2 & 142 & 0.93 \\
\hline
\end{tabular}




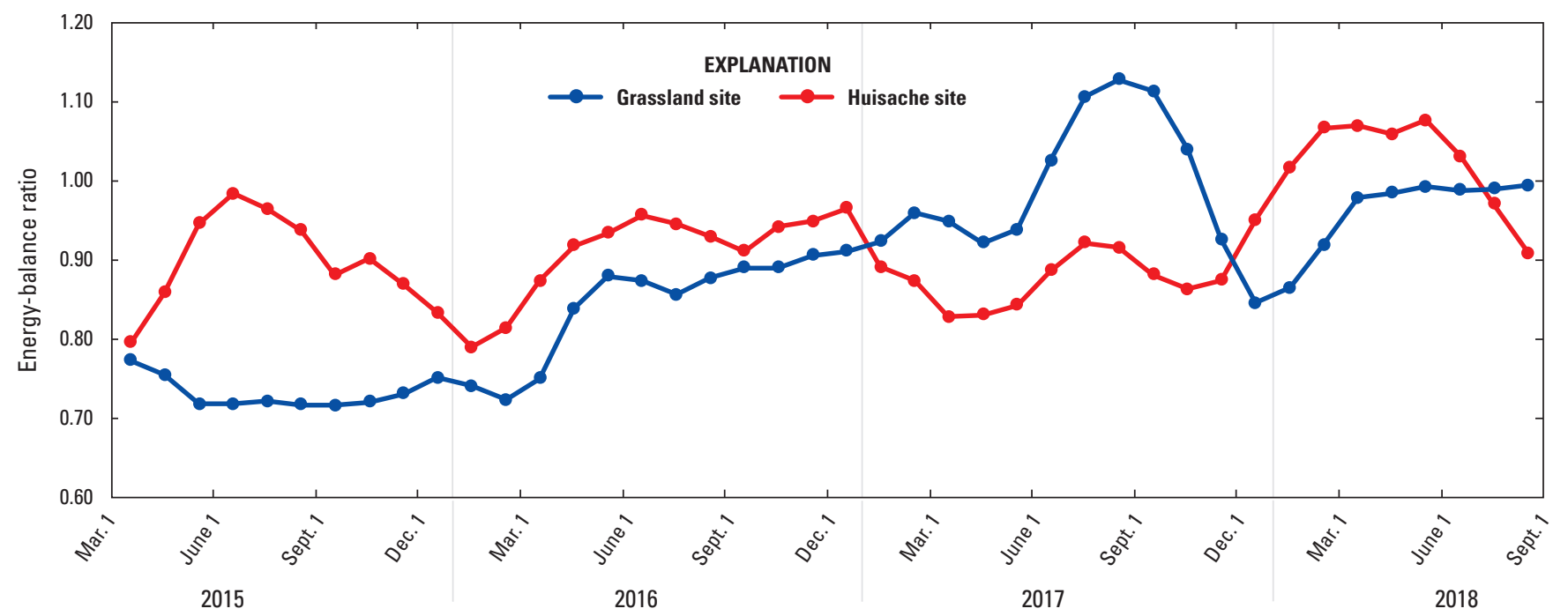

Figure 10. Three-month moving average of the monthly energy-balance ratio, grassland site and huisache site, Victoria County, Texas, March 2015-August 2018.

\section{Remote Sensing of Evapotranspiration}

Evapotranspiration estimates were derived from Landsat optical and thermal imagery by using the METRIC and SSEBop surface energy-balance models (Allen and others, 2007; Senay, 2018). These estimates were developed to both complement the EC data and provide additional information about how evapotranspiration rates differ between grassland and huisache sites at larger spatial scales. New Landsat imagery is available every 16 days from the Landsat 8 satellite; two types of imagery are collected by Landsat 8 , Optical Land Imager (OLI) imagery and Thermal Infrared Sensor (TIRS) imagery (National Aeronautics and Space Administration, 2019a). Landsat imagery acquired during the study period has a native spatial resolution of $30 \mathrm{~m}$ for optical channels and $60-100 \mathrm{~m}$ for thermal channels. Landsat imagery is also collected by the Landsat 7 satellite Enhanced Thematic Mapper Plus (ETM+) that, when combined with imagery from Landsat 8 , provides Landsat imagery every 8 days (National Aeronautics and Space Administration, 2019b). Cloud cover during the time of image collection reduces the total number of usable images. The study area was contained entirely within path 26 row 40 of the Worldwide Reference System-2 used by the Landsat program (National Aeronautics and Space Administration, 2019c). Images used in the METRIC model were manually selected, with images being rejected when the study area was obscured by clouds or cloud shadows.

Reference evapotranspiration, surface temperature, albedo, vegetation indices, and land cover were primary inputs for the METRIC model, whereas surface temperature, air temperature, and reference evapotranspiration were primary inputs for the SSEBop model. METRIC has a built-in calibration method that involves the selection of cold and hot calibration pixels that represent conditions where maximum evapotranspiration and minimum evapotranspiration are occurring, respectively; this built-in calibration method is referred to as Calibration Using Inverse Modeling at Extreme Conditions (CIMEC) (Allen and others, 2013). Iterative selection of cold and hot pixels and calibration of METRIC was done manually, with initial selections based on the results from the CIMEC automated calibration method (Allen and others, 2013; Western States Water Use Program, 2019). SSEBop has no calibration process and was executed on Google Earth Engine by using batch scripts and suggested properties and datasets outlined in Senay (2018).

Daily $E T_{r}$ was used in both the METRIC and SSEBop models to calculate $E T_{r} F$ (where $E T_{r} F=E T / E T_{r}$ ) for each Landsat image and to perform temporal interpolation of $E T_{r} F$ and time integration of evapotranspiration between Landsat image acquisitions. $E T_{r} F$ is analogous to the commonly used crop coefficient in the agricultural engineering literature (Allen and others, 1996) but is representative of actual evaporative conditions instead of well-watered conditions inherent in the traditional crop coefficient approach.

Monthly and annual remotely sensed evapotranspiration values were estimated as

$$
E T_{R S}=\sum_{i=m}^{n}\left(E T_{r} F_{i} * E T_{r 24 i}\right)
$$

where

$$
\begin{array}{cl}
E T_{R S} \quad \begin{array}{l}
\text { is the cumulative evapotranspiration for a } \\
\text { period beginning on day } m \text { and ending on }
\end{array} \\
\text { day } n \text {, in millimeters; } \\
E T_{r} F_{i} \quad \begin{array}{l}
\text { is the fraction of daily reference } \\
\text { evapotranspiration }\left(E T_{r}\right) \text { for day } i \\
\text { (dimensionless); and }
\end{array} \\
E T_{r 24 i} \quad \begin{array}{l}
\text { is the 24-hour daily reference } \\
\text { evapotranspiration total, in millimeters per } \\
\text { day for day } i .
\end{array}
\end{array}
$$


Temporal per-pixel linear interpolation of $E T_{r} F$ in between satellite image dates was performed to estimate daily values of $E T_{r} F$. Because the satellite imagery only provides data for the day the image was acquired, daily $E T_{r}$ is multiplied by the daily interpolated $E T_{r} F$. The use of $E T_{r}$ accounts for daily and seasonal variations in atmospheric water demand, whereas $E T_{r} F$ accounts for plant phenological stages, stress, and management such as harvest, cuttings, and fallowing. A minimum of one cloud-free $E T_{r} F$ image per month is desired to track plant phenology and any changes in cover, but some months did not have cloud-free imagery. Therefore, linearly interpolated values of $E T_{r} F$ were used.

$E T_{r}$ was derived by using spatially distributed meteorological variables from gridMET (Abatzoglou, 2013; University of Idaho, 2019) and applying the standardized American Society of Civil Engineers standardized Penmen-Monteith reference evapotranspiration equation to the dataset (Allen and others, 2005). Site-specific daily $E T_{r}$ was estimated by multiplying gridMET-derived $E T_{r}$ by a bias-correction factor. The bias-correction factor was calculated as the ratio of $E T_{r}$ (determined from meteorological data collected from the grassland site) to gridMET $E T_{r}$. The average bias-correction factor for the study period (that is, the sum of study period grassland site daily $E T_{r}$ divided by the sum of study period daily gridMET $E T_{r}$ ) was 0.85 .

Bias-corrected gridMET $E T_{r}$ was multiplied by METRIC and SSEBop per-pixel daily interpolated $E T_{r} F$ to develop per-pixel daily evapotranspiration estimates for each site (eq. 8). Monthly values of remotely sensed evapotranspiration $\left(\mathrm{ET}_{\mathrm{RS}}\right)$ are available in Slattery (2020).

\section{Effects of Huisache Removal on Evapotranspiration}

The effect of huisache removal on evapotranspiration was evaluated by comparing the difference in evapotranspiration rates between the grassland and huisache sites during the pre-removal and post-removal periods. Differences in evapotranspiration between the sites were evaluated by analyzing monthly $\mathrm{ET}_{\mathrm{C}}$ and remote sensing evapotranspiration $\left(E_{\mathrm{RS}}\right)$ estimated by METRIC and SSEBop techniques. The differences in evapotranspiration rates between the two sites are considered estimates of the differences in the water available for surface runoff and groundwater recharge between the two sites, as well as possible increased water availability, that can be realized through huisache removal.

Table 6 summarizes annual rainfall and pre- and post-removal period $\mathrm{ET}_{\mathrm{C}}$ and $\mathrm{ET}_{\mathrm{RS}}$ (METRIC and SSEBop). Figure 11 shows a plot of monthly $\mathrm{ET}_{\mathrm{C}}$ and $\mathrm{ET}_{\mathrm{RS}}(\mathrm{METRIC}$ and SSEBop) at the two sites over the study period. Monthly values of $\mathrm{ET}_{\mathrm{C}}$ and $\mathrm{ET}_{\mathrm{RS}}$ are available in Slattery (2020).

Table 6. Summary of rainfall and evapotranspiration totals for the grassland and huisache study sites, March 2015-August 2018.

$\left[\mathrm{mm} / \mathrm{mo}\right.$, millimeter per month; $\mathrm{ET}_{\mathrm{C}}$, corrected eddy-covariance evapotranspiration; $\mathrm{ET}_{\mathrm{RS}}$, remotely sensed evapotranspiration; METRIC, Mapping Evapotranspiration With Internalized Calibration; SSEBop, Operational Simplified Surface Energy Balance]

\begin{tabular}{|c|c|c|c|c|c|c|}
\hline & $\begin{array}{c}2015 \\
\text { (Mar.-Dec.) }\end{array}$ & $\begin{array}{c}2016 \\
\text { (Jan.-Dec.) }\end{array}$ & $\begin{array}{c}2017 \\
\text { (Jan.-Dec.) }\end{array}$ & $\begin{array}{c}2018 \\
\text { (Jan.-Aug.) }\end{array}$ & $\begin{array}{l}\text { Pre-removal } \\
\text { Mar. 2015- } \\
\text { Dec. } 2016\end{array}$ & $\begin{array}{c}\text { Post-removal } \\
\text { Feb. 2017- } \\
\text { Aug. } 2018\end{array}$ \\
\hline $\mathrm{ET}_{\mathrm{C}}$, grassland site $(\mathrm{mm} / \mathrm{mo})$ & 89.9 & 86.4 & 100.0 & 90.6 & 88.0 & 99.2 \\
\hline $\mathrm{ET}_{\mathrm{C}}$, huisache site $(\mathrm{mm} / \mathrm{mo})$ & 104.2 & 94.2 & 75.6 & 75.9 & 98.7 & 77.8 \\
\hline $\mathrm{ET}_{\mathrm{RS}}(\mathrm{METRIC})$, huisache site $(\mathrm{mm} / \mathrm{mo})$ & 105.6 & 99.1 & 61.7 & 96.1 & 102.0 & 77.2 \\
\hline $\mathrm{ET}_{\mathrm{RS}}(\mathrm{SSEBop})$, grassland site $(\mathrm{mm} / \mathrm{mo})$ & 97.4 & 79.5 & 61.0 & 68.7 & 87.6 & 66.2 \\
\hline $\mathrm{ET}_{\mathrm{RS}}(\mathrm{SSEBop})$, huisache site $(\mathrm{mm} / \mathrm{mo})$ & 107.9 & 100.3 & 54.1 & 61.6 & 103.8 & 58.9 \\
\hline $\begin{array}{l}\text { Average METRIC and SSEBop ET } \text { RS }_{\text {, }} \\
\text { huisache site }(\mathrm{mm} / \mathrm{mo})\end{array}$ & 106.7 & 99.7 & 57.9 & 78.8 & 102.9 & 68.0 \\
\hline $\begin{array}{l}\text { Average of eddy covariance and average } \\
\mathrm{ET}_{\mathrm{RS}} \text {, grassland site }(\mathrm{mm} / \mathrm{mo})\end{array}$ & 93.6 & 82.5 & 83.4 & 89.1 & 87.6 & 88.5 \\
\hline $\begin{array}{l}\text { Average of eddy covariance and average } \\
\mathrm{ET}_{\mathrm{RS}} \text {, huisache site }(\mathrm{mm} / \mathrm{mo})\end{array}$ & 105.4 & 96.9 & 66.8 & 77.3 & 100.8 & 72.9 \\
\hline
\end{tabular}




\section{A. Grassland site}
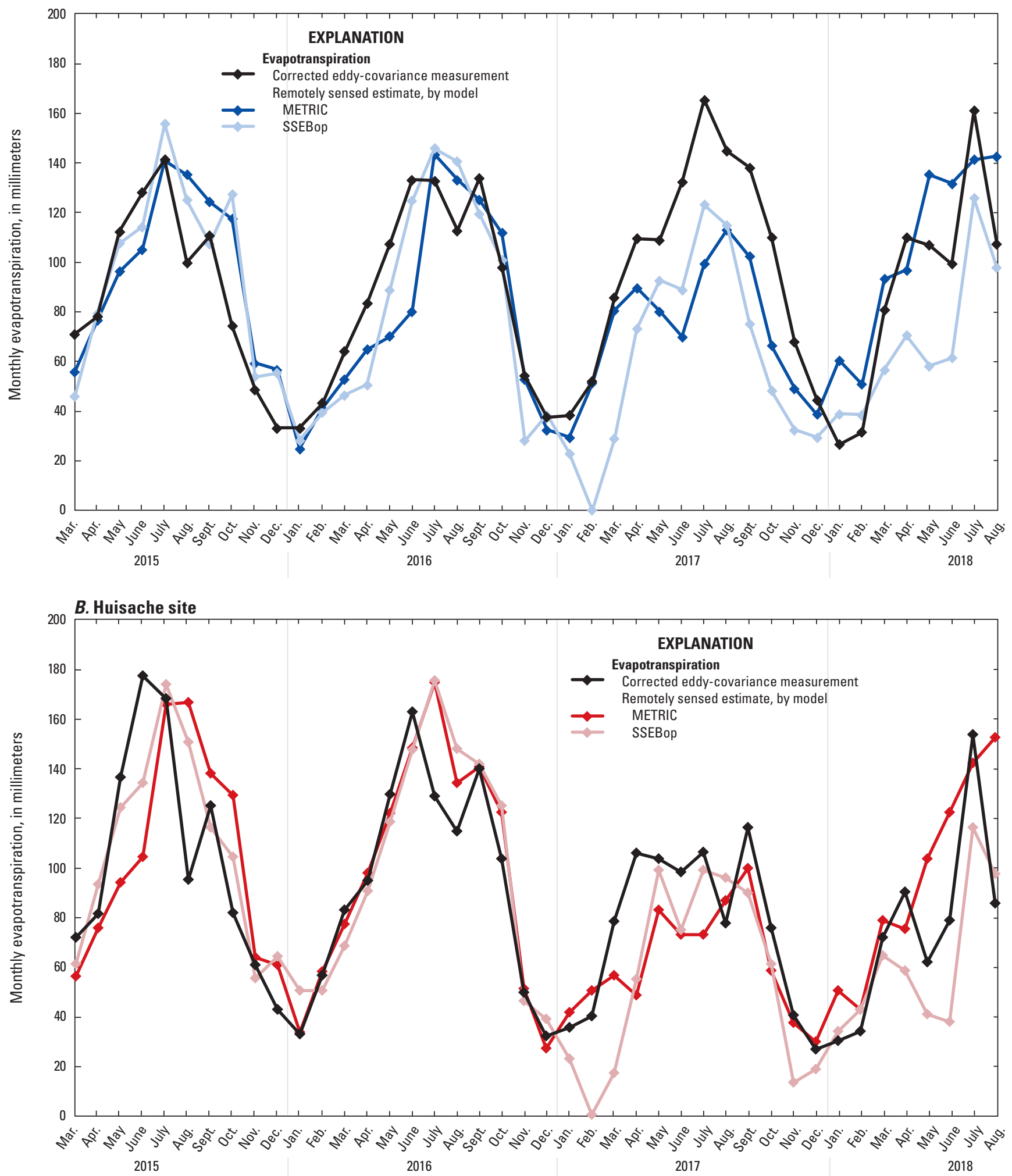

METRIC, Mapping Evapotranspiration With Internalized Calibration model (Allen and others, 2007)

SSEBop, Operational Simplified Surface Energy Balance model (Senay, 2018)

Figure 11. Comparison of corrected eddy-covariance monthly evapotranspiration and remotely sensed (METRIC and SSEBop) monthly evapotranspiration at $A$, the grassland site and $B$, the huisache site, Victoria County, Texas, March 2015-August 2018. 
Figure 11 indicates good agreement between monthly $\mathrm{ET}_{\mathrm{C}}$ and $\mathrm{ET}_{\mathrm{RS}}$ estimates at both sites. For the overall study period $\mathrm{ET}_{\mathrm{C}}$ was greater than the average METRIC and SSEBop $\mathrm{ET}_{\mathrm{RS}}$ by about 11 percent at the grassland site and about 2 percent at the huisache site. The average grassland site $\mathrm{ET}_{\mathrm{C}}$ for the pre-removal period (March 2015-December 2016) was 88.0 millimeters per month $(\mathrm{mm} / \mathrm{mo})$, compared with $87.1 \mathrm{~mm} / \mathrm{mo}$ determined by the average of the remote-sensing methods (METRIC and SSEBop) (table 6). The average huisache site $\mathrm{ET}_{\mathrm{C}}$ for the pre-removal period was $98.7 \mathrm{~mm} / \mathrm{mo}$, compared with $102.9 \mathrm{~mm} / \mathrm{mo}$ determined by the average of the remote-sensing methods (table 6). The pre-removal period evapotranspiration at the grassland site based on the average of $\mathrm{ET}_{\mathrm{C}}$ and the average $\mathrm{ET}_{\mathrm{RS}}$ was $87.6 \mathrm{~mm} / \mathrm{mo}$. The pre-removal period evapotranspiration at the huisache site based on the average of the $\mathrm{ET}_{\mathrm{C}}$ measurement and the average $\mathrm{ET}_{\mathrm{RS}}$ estimate was $100.8 \mathrm{~mm} / \mathrm{mo}$ (table 6).

During the post-removal period (February 2017August 2018), the average grassland site $\mathrm{ET}_{\mathrm{C}}$ was $99.2 \mathrm{~mm} / \mathrm{mo}$, compared with the average $\mathrm{ET}_{\mathrm{RS}}$ of $77.8 \mathrm{~mm} / \mathrm{mo}$. The average huisache site $\mathrm{ET}_{\mathrm{C}}$ for the post-removal period was $77.8 \mathrm{~mm} / \mathrm{mo}$, compared with the average $\mathrm{ET}_{\mathrm{RS}}$ of $68.0 \mathrm{~mm} / \mathrm{mo}$ (table 6 ). The post-removal period evapotranspiration at the grassland site based on the average of the $\mathrm{ET}_{\mathrm{C}}$ measurement and the average $\mathrm{ET}_{\mathrm{RS}}$ estimate was $88.5 \mathrm{~mm} / \mathrm{mo}$. The post-removal period evapotranspiration at the huisache site based on the average of the $\mathrm{ET}_{\mathrm{C}}$ measurement and the average $\mathrm{ET}_{\mathrm{RS}}$ estimate was $72.9 \mathrm{~mm} / \mathrm{mo}$ (table 6).
The monthly cumulative difference in evapotranspiration rates between the huisache and grassland sites $\left(\mathrm{ET}_{\text {huisache }}-\mathrm{ET}\right.$ grassland) are shown in figure 12. The cumulative difference in evapotranspiration rates is shown for $\mathrm{ET}_{\mathrm{C}}$, the average $\mathrm{ET}_{\mathrm{RS}}$ (METRIC and SSEBop), and the average of $\mathrm{ET}_{\mathrm{C}}$ and the average $\mathrm{ET}_{\mathrm{RS}}$.

In figure 12, both evapotranspiration methods show that during 2015-16 (pre-removal period) the cumulative difference between huisache site evapotranspiration and grassland site evapotranspiration ( $\mathrm{ET}_{\text {huisache }}-\mathrm{ET}_{\text {grassland }}$ ) is increasing - $\mathrm{ET}_{\text {huisache }}$ is consistently greater than $\mathrm{ET}$ grassland. Around October-November 2016, the cumulative difference between evapotranspiration rates levels off, indicating that the evapotranspiration rates at the two sites are about the same, likely because the vegetation at both sites is, to some extent, entering dormancy and evapotranspiration rates at both sites are relatively low. During January 2017, huisache vegetation was removed at the huisache site. By mid-May 2017, the cumulative difference in evapotranspiration was observed to decrease, indicating that the evapotranspiration rate at the huisache site was less than that at the grassland site. From December 2017 to March 2018 (huisache dormant season), both methods show relatively little or no change in the cumulative difference in evapotranspiration. Starting around April 2018, the cumulative difference in evapotranspiration again decreases through the growing season until the end of August 2018, indicating that the evapotranspiration at the grassland site was greater than the evapotranspiration measured at the huisache site.

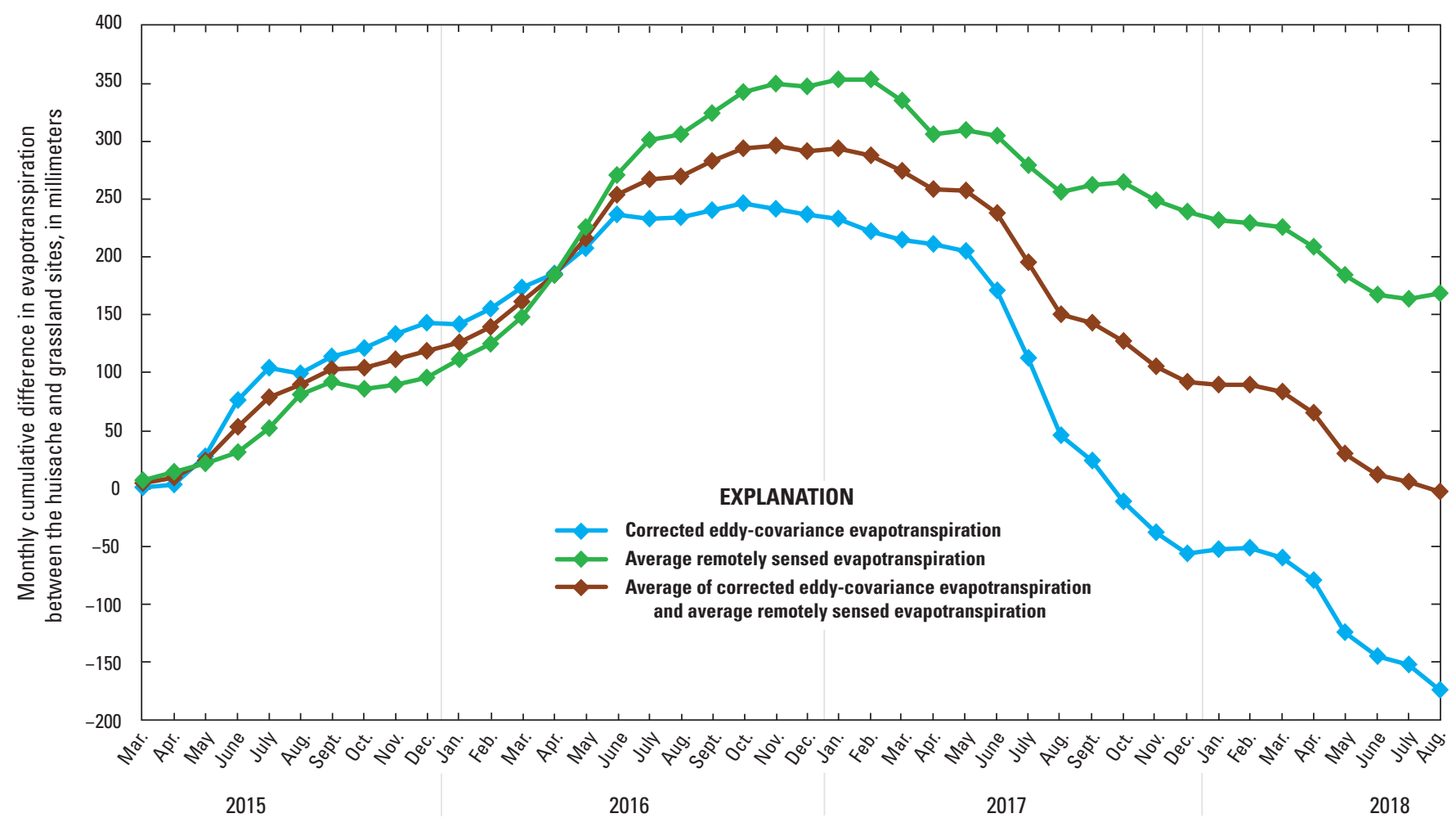

Figure 12. Monthly cumulative difference in evapotranspiration between huisache and grassland sites, by eddycovariance and remotely sensed evapotranspiration methods, Victoria County, Texas, March 2015-August 2018. 
Selected statistics for the monthly difference in evapotranspiration between the huisache site and the grassland site $\left(\mathrm{ET}_{\text {huisache }}-\mathrm{ET}_{\text {grassland }}\right)$ before and after huisache removal are listed in table 7. Statistics are provided for both $\mathrm{ET}_{\mathrm{C}}$ and $\mathrm{ET}_{\mathrm{RS}}$. The pre-removal period was March 2015 through December 2016. The post-removal period was February 2017 through August 2018. Huisache vegetation was being removed from the huisache site during January 2017. So, January 2017 data were excluded from the statistical analysis (table 7).

During the pre-removal period, the trend of monthly $\mathrm{ET}_{\text {huisache }}-\mathrm{ET}$ grassland was similar for both the EC and RS methods. The average monthly ET husache $-\mathrm{ET}_{\text {grassland }}$ for the EC method during the pre-removal period was $10.7 \mathrm{~mm} / \mathrm{mo}$. The average monthly $\mathrm{ET}_{\text {huisache }}-\mathrm{ET}_{\text {grassland }}$ for the RS method during the pre-removal period was $15.8 \mathrm{~mm} / \mathrm{mo}$. The 95 -percent confidence interval of the average difference was 4.7 to $16.8 \mathrm{~mm} / \mathrm{mo}$ for $\mathrm{ET}_{\mathrm{C}}$ and 9.7 to $21.9 \mathrm{~mm} / \mathrm{mo}$ for $\mathrm{ET}_{\mathrm{RS}}$ (table 7).

During the post-removal period, the average monthly $\mathrm{ET}_{\text {huisache }}-\mathrm{ET}_{\text {grassland }}\left(\mathrm{ET}_{\mathrm{C}}\right)$ was $-21.4 \mathrm{~mm} / \mathrm{mo}$. The average monthly $\mathrm{ET}_{\text {huisache }}-\mathrm{ET}_{\text {grassland }}\left(\mathrm{ET}_{\mathrm{RS}}\right)$ was $-9.8 \mathrm{~mm} / \mathrm{mo}$. The 95-percent confidence interval of the average difference was -30.8 to $-12.0 \mathrm{~mm} / \mathrm{mo}^{\left(E T_{\mathrm{C}}\right)}$ and -15.2 to $-4.3 \mathrm{~mm} / \mathrm{mo}^{(}\left(\mathrm{ET}_{\mathrm{RS}}\right)$ (table 7). For both evapotranspiration methods, one-sided, Kruskall-Wallis tests indicate statistically significant differences (alpha level of 0.05 ) in evapotranspiration rates (Helsel and Hirsch, 2002) between the pre-removal and post-removal periods. The p-values (Helsel and Hirsch, 2002) for the tests were less than 0.01 .

It might be expected that after huisache removal the evapotranspiration rates at the huisache site would be similar to those at the grassland site because both sites were then grassland sites. After huisache removal, native grasses emerged very quickly at the huisache site, as can be seen from figures 5 and 7 . However, the grass density and root development were likely at a less mature stage compared with the original grassland site. Therefore, the emergent grasses at the huisache site were not able to utilize as much water for evapotranspiration as those at the original grassland site. Also, the physical removal of huisache likely resulted in alteration of the soils, possibly affecting infiltration and runoff rates, which could affect evapotranspiration. As a result, evapotranspiration at the huisache site was actually lower than that at the grassland site during the post-removal period. Therefore, the pre-removal period likely provides the best characterization of the difference in evapotranspiration between the huisache and grassland sites. During the pre-removal period, huisache $\mathrm{ET}_{\mathrm{C}}$ was greater than grassland $\mathrm{ET}_{\mathrm{C}}$ by an average of about $10.7 \mathrm{~mm} / \mathrm{mo}$ as measured by EC method. As determined by the average of the METRIC and SSEBop remote-sensing techniques, huisache $\mathrm{ET}_{\mathrm{RS}}$ was greater than grassland $\mathrm{ET}_{\mathrm{RS}}$ by an average of $15.8 \mathrm{~mm} / \mathrm{mo}$ during the pre-removal period.

Rainfall was above average during each calendar year of the study, especially during the pre-removal period (Slattery, 2020); therefore, the data collected during the study might be inadequate to describe evapotranspiration differences between the huisache and grassland sites during extended dry periods. During some months of low rainfall (for example, July 2015, July 2016, and October 2016), monthly evapotranspiration exceeded monthly rainfall because residual soil moisture from previous months was available for evapotranspiration (Slattery, 2020). As a result, there is poor correlation between monthly rainfall and monthly differences in evapotranspiration between sites. During dry periods, evapotranspiration rates for both sites would likely be low because of lack of available water, and differences in evapotranspiration between sites could be small.

One of the anticipated changes of huisache removal is increased water availability for groundwater recharge and surface-water runoff to streams because of reduced

Table 7. Selected statistics for the monthly difference in evapotranspiration between the huisache site and grassland site ( $E T_{\text {huisache }}-\mathrm{ET}_{\text {grassland }}$ ) before and after huisache removal.

[SSEBop, Operational Simplified Surface Energy Balance; METRIC, Mapping Evapotranspiration With Internalized Calibration; pre-removal period is March 2015-December 2016; post-removal period is February 2017-August 2018; mm, millimeter]

\begin{tabular}{|c|c|c|c|c|}
\hline \multirow[t]{2}{*}{ Statistic } & \multicolumn{2}{|c|}{$\begin{array}{l}\text { Corrected eddy-covariance } \\
\text { evapotranspiration } \\
\left(E T_{c}\right)\end{array}$} & \multicolumn{2}{|c|}{$\begin{array}{l}\text { Average of SSEBop and METRIC } \\
\text { remotely sensed evapotranspiration } \\
\left(E T_{\mathrm{RS}}\right)\end{array}$} \\
\hline & Pre-removal & Post-removal & Pre-removal & Post-removal \\
\hline Number of monthly values & 22 & 19 & 22 & 19 \\
\hline Sum (mm) & 236.1 & -407.0 & 347.3 & -185.3 \\
\hline Average (mm) & 10.7 & -21.4 & 15.8 & -9.8 \\
\hline Standard deviation (mm) & 13.6 & 19.5 & 13.7 & 11.2 \\
\hline Variance (mm) & 184.7 & 379.7 & 188.3 & 126.4 \\
\hline Minimum (mm) & -5.4 & -67.1 & -5.7 & -29.7 \\
\hline Maximum (mm) & 49.2 & 3.3 & 45.5 & 5.9 \\
\hline
\end{tabular}


evapotranspiration. Groundwater recharge and surface-water runoff were not measured as part of this study, and the distribution of available water for groundwater recharge or surface-water runoff cannot be determined, but a simple estimate of the possible difference in available water for groundwater recharge and surface-water runoff between the huisache and grassland sites can be calculated as the difference in evapotranspiration rates between the sites ( $\mathrm{ET}_{\text {huisache }}-\mathrm{ET}_{\text {grassland }}$ ) as shown in figure 12. The average monthly differences in evapotranspiration rates for pre- and post-removal periods, as calculated from $\mathrm{ET}_{\mathrm{C}}$, average $\mathrm{ET}_{\mathrm{RS}}$, and the average of the $\mathrm{ET}_{\mathrm{C}}$ and average $\mathrm{ET}_{\mathrm{RS}}$, are summarized in table 8 .

During the pre-removal period, the average $\mathrm{ET}_{\text {huisache }}$ - ET grassland was $10.7 \mathrm{~mm} / \mathrm{mo}$, as estimated by the EC measurements. The average ET huisache $-\mathrm{ET}_{\text {grassland }}$ was $15.8 \mathrm{~mm} / \mathrm{mo}$, as estimated by the average of the METRIC and SSEBop remote-sensing techniques. The average monthly difference in evapotranspiration, determined by an average of the EC and RS methods, was $13.2 \mathrm{~mm} / \mathrm{mo}$ (table 8). This value represents the best estimate of the increase in water available for groundwater recharge or surface-water runoff at the grassland site, compared to the huisache site.

During the post-removal period, because the huisache evapotranspiration was consistently less than the grassland evapotranspiration, the trend is reversed, and compared with the huisache site, less water was available at the grassland site for groundwater recharge and surface-water runoff by an average of $15.6 \mathrm{~mm} / \mathrm{mo}$ (table 8 ). Because the pre-removal period represents a period where the sites could be characterized as mature, undisturbed grassland and huisache environments, the pre-removal period likely provides the most reasonable estimate of long-term differences in evapotranspiration rates and potential for water savings through huisache removal. Also, because rainfall conditions during the study were average to above average and did not include an extended dry period, the observed effect of huisache removal on evapotranspiration and water availability is possibly different during extended dry periods.

\section{Mapping Evapotranspiration by Remote Sensing}

A map of remotely sensed annual evapotranspiration for 2015 for an approximately $400-\mathrm{km}^{2}$ area surrounding the study area is shown in figure 13 (Slattery, 2020). The remotely sensed evapotranspiration shown is the average of model outputs from the METRIC and SSEBop techniques. The map demonstrates the capability of remote sensing to evaluate land-management effects on evapotranspiration for larger scale areas, such as a county or stream-basin area.

Lower evapotranspiration rates are shown as yellow and orange cells that generally represent grassland, cropland, bare ground, and developed areas. Map cells of higher evapotranspiration rates tend toward shades of green and generally represent areas of denser vegetation, flood plains, and water bodies. The difference in evapotranspiration between the grassland site (yellow) and huisache site (green) during 2015 is apparent in figure 13. Evapotranspiration within the map extent ranges from $225 \mathrm{~mm}$ per year to $1,690 \mathrm{~mm}$ per year. The map resolution is $30 \mathrm{~m}$ by $30 \mathrm{~m}$, although the true resolution of the map is limited by the resolution of the Landsat thermal imagery data, which is $100 \mathrm{~m}$ by $100 \mathrm{~m}$. The map illustrates relatively high-resolution evapotranspiration data, which can be used to analyze and evaluate land-management effects on evapotranspiration for large areas.

Table 8. Average monthly difference between huisache site and grassland site evapotranspiration before huisache removal (pre-removal period) and after huisache removal (post-removal period) for eddy-covariance and remote-sensing estimates.

[ET, evapotranspiration; $\mathrm{ET}_{\mathrm{C}}$, corrected eddy-covariance evapotranspiration; $\mathrm{ET}_{\mathrm{RS}}$, remotely sensed evapotranspiration]

\begin{tabular}{llcc}
\hline & & \multicolumn{2}{c}{$\begin{array}{c}\text { Average monthly differences } \\
\text { in evapotranspiration }\end{array}$} \\
\cline { 3 - 4 } $\begin{array}{c}\text { Differences in } \\
\text { evapotranspiration }\end{array}$ & \multicolumn{1}{c}{$\begin{array}{c}\text { Measurement } \\
\text { type }\end{array}$} & $\begin{array}{c}\text { Pre-removal } \\
\text { Mar. 2015- } \\
\text { Dec. 2016 } \\
\text { (millimeters } \\
\text { per month) }\end{array}$ & $\begin{array}{c}\text { Post-removal } \\
\text { Feb. 2017- } \\
\text { Aug. 2018 } \\
\text { (millimeters } \\
\text { per month) }\end{array}$ \\
\hline ET huisache-ET grassland & $\mathrm{ET}_{\mathrm{C}}$ & 10.7 & -21.4 \\
ET huisache-ET grassland & $\mathrm{ET}_{\mathrm{RS}}$ & 15.8 & -9.8 \\
ET huisache-ET grassland & average of $\mathrm{ET}_{\mathrm{C}}$ and $\mathrm{ET}_{\mathrm{RS}}$ & 13.2 & -15.6 \\
\hline
\end{tabular}




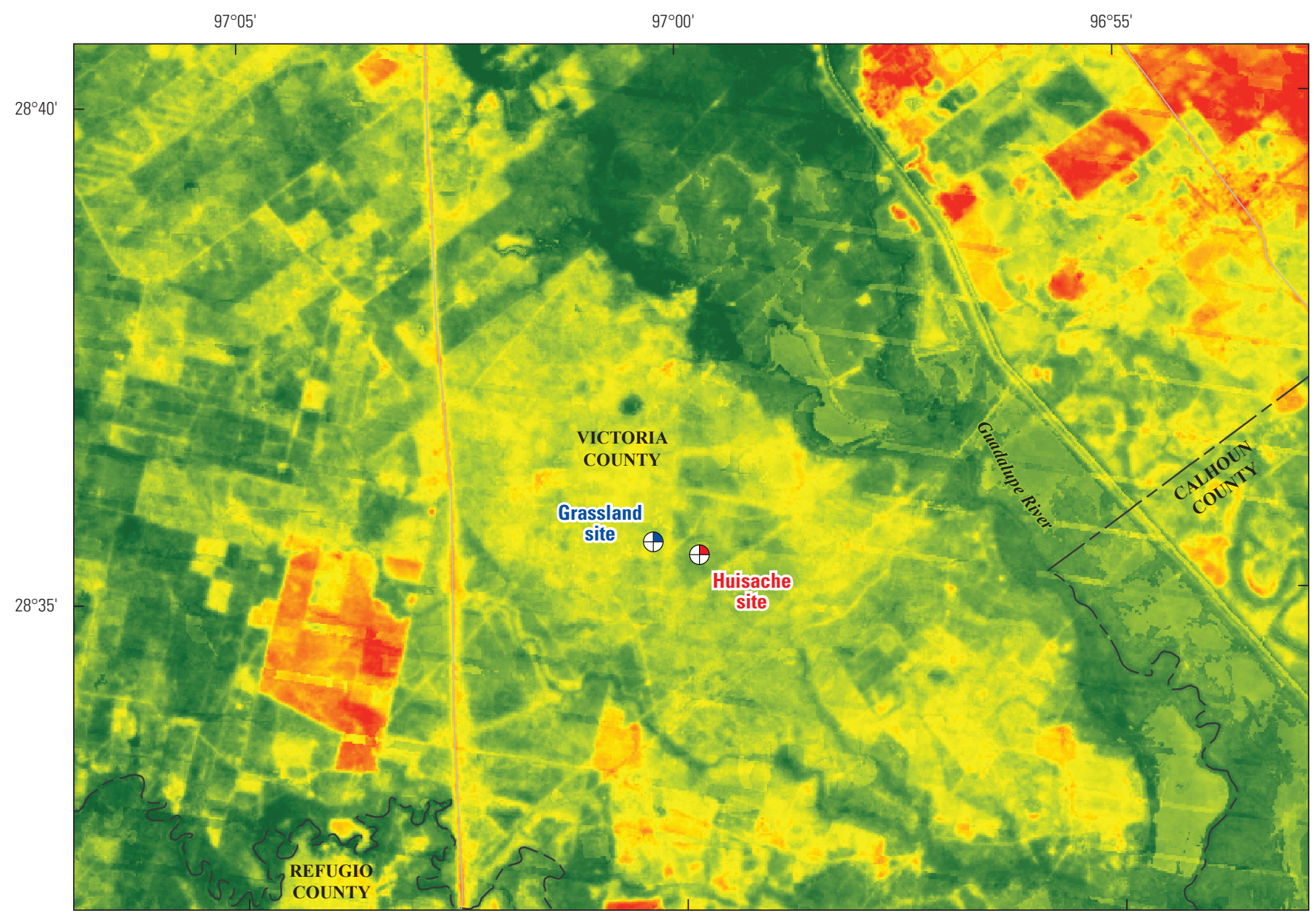

Base modified from U.S. Geological Survey 1:100,000 scale digital data Texas South-Central State Plane coordinate system North American Datum of 1983
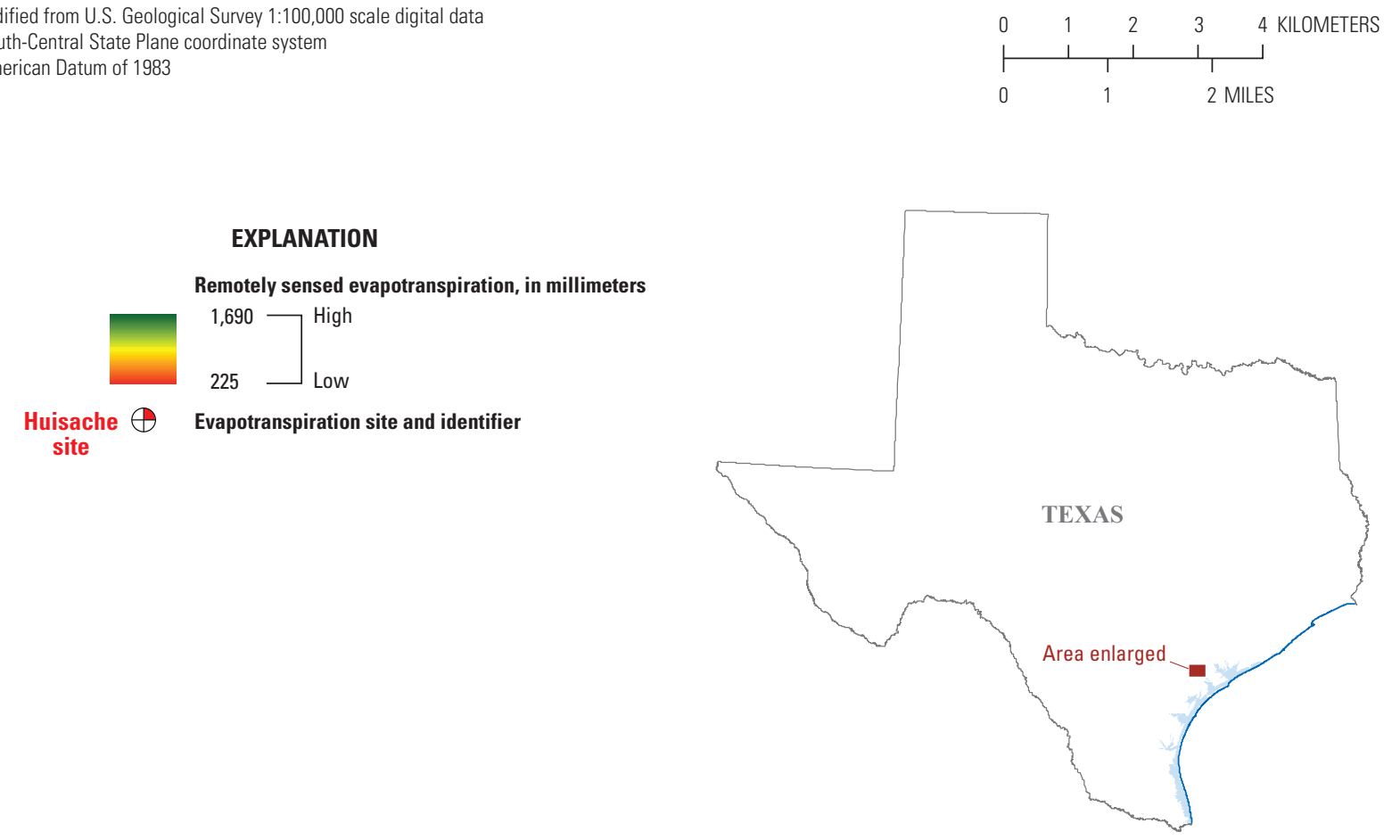

Figure 13. Remotely sensed 2015 annual evapotranspiration rates for the study sites and surrounding area, Victoria County, Texas. 


\section{Summary}

Much of the historical oak-grassland landcover across Texas has undergone woody-plant encroachment attributed to fire suppression and overgrazing. One of the encroaching species is Vachellia farnesiana var. farnesiana (huisache), a woody plant that can grow 5-8 meters tall and uses an extensive root system to access both shallow soil water and deeper groundwater. Huisache is a prolific seed producer and can overtake a grassland prairie in a generation. Once established, it can readily outcompete other native grasses for space, often resulting in areas with diminished grazing benefits. Because of its prolific spread and potential water uptake, huisache removal could affect groundwater recharge and/or surface-water supply.

By removing woody vegetation such as huisache and allowing native grasses to reestablish, the hydrologic budget of the watershed might change to increase groundwater recharge and surface-water supply. One method of documenting changes to the hydrologic budget resulting from differences in vegetative cover is by measuring evapotranspiration rates.

The U.S. Geological Survey and the Desert Research Institute, in cooperation with various Federal, State, and local agencies, studied the effects of huisache removal on evapotranspiration and the hydrologic budget on rangeland in Victoria County in south-central Texas during 2015-18. Federal, State, and local agencies that cooperated on the study were the Natural Resources Conservation Service, Texas State Soil and Water Conservation Board, Victoria County Groundwater Conservation District, Victoria Soil and Water Conservation District, and the San Antonio River Authority.

Measurements of evapotranspiration, rainfall, and other related properties were collected at two sites during March 2015 through August 2018. One site was predominantly grassland. The other site was dominated by dense huisache vegetation that was removed about halfway through the study period. The resulting evapotranspiration datasets were examined for differences between the locations and differences between the pre-removal (2015-16) and post-removal (2017-18) periods to assess the effects of huisache removal on evapotranspiration.

Evapotranspiration data were collected by two methods and used to evaluate differences in evapotranspiration between the grassland site and the huisache site. First, eddy-covariance stations were installed at each of the study sites, and evapotranspiration and energy-balance data were collected from March 2015 through August 2018. Second, remotely sensed data (satellite optical and thermal imagery) were processed to estimate monthly evapotranspiration by using the Mapping Evapotranspiration at High Resolution With Internalized Calibration (METRIC) and Operational Simplified Surface Energy Balance (SSEBop) models.

After evapotranspiration data were collected at the grassland and huisache sites through December 2016, the huisache site was cleared of huisache in January 2017. Evapotranspiration data collection continued at both sites through August 2018.
Corrected eddy-covariance evapotranspiration $\left(\mathrm{ET}_{\mathrm{C}}\right)$ correlated well with remote sensing evapotranspiration $\left(\mathrm{ET}_{\mathrm{RS}}\right)$ on a monthly basis. However, for the overall study period, average $\mathrm{ET}_{\mathrm{EC}}$ was greater than the average $\mathrm{ET}_{\mathrm{RS}}$ by about 11 percent at the grassland site and 2 percent at the huisache site.

During the pre-removal period, evapotranspiration was greater at the huisache site than at the grassland site. Grassland site evapotranspiration (average of $\mathrm{ET}_{\mathrm{C}}$ and $\mathrm{ET}_{\mathrm{RS}}$ ) was 87.6 millimeters per month $(\mathrm{mm} / \mathrm{mo})$, and huisache site evapotranspiration was $100.8 \mathrm{~mm} / \mathrm{mo}$. After huisache was removed from the huisache site in January 2016, the post-removal period (February 2017-August 2018) evapotranspiration was $88.5 \mathrm{~mm} / \mathrm{mo}$ at the grassland site and $72.9 \mathrm{~mm} / \mathrm{mo}$ at the huisache site.

The monthly differences in evapotranspiration between the grassland and huisache sites were compared between the pre-removal and post-removal periods and exhibited statistically significant differences at the 95 percent confidence level. The average monthly difference in huisache site evapotranspiration and grassland evapotranspiration (huisache site evapotranspiration minus grassland site evapotranspiration) during the pre-removal period was $10.7 \mathrm{~mm} / \mathrm{mo}\left(\mathrm{ET}_{\mathrm{C}}\right)$ and $15.8 \mathrm{~mm} / \mathrm{mo}\left(\mathrm{ET}_{\mathrm{RS}}\right)$ - the huisache site exhibited greater evapotranspiration. During the post-removal period, the average monthly difference in evapotranspiration

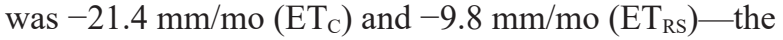
huisache site evapotranspiration was less than grassland site evapotranspiration during this period.

It might be expected that after huisache removal the evapotranspiration rates at the huisache site would be similar to those at the grassland site because both sites were then grassland sites. After huisache removal, native grasses emerged very quickly at the huisache site. However, the grass density and root development were likely at a less mature stage at the huisache site compared with the grassland site. Therefore, the emergent grasses at the huisache site were not able to utilize as much water for evapotranspiration as were the grasses at the grassland site. Also, the physical removal of huisache likely resulted in alteration of the soils, possibly affecting infiltration and runoff rates, which could affect evapotranspiration. As a result, evapotranspiration at the huisache site was actually lower than that at the grassland site after huisache removal. Therefore, the pre-removal period provides the best characterization of the difference in evapotranspiration between the huisache and grassland sites. During the pre-removal period, huisache $\mathrm{ET}_{\mathrm{C}}$ was greater than grassland $\mathrm{ET}_{\mathrm{C}}$ by an average of about $10.7 \mathrm{~mm} / \mathrm{mo}$ as measured by EC method. As determined by the average of the METRIC and SSEBop remote-sensing techniques, huisache $\mathrm{ET}_{\mathrm{RS}}$ was greater than grassland $\mathrm{ET}_{\mathrm{RS}}$ by an average of $15.8 \mathrm{~mm} / \mathrm{mo}$ during the pre-removal period. The average monthly difference in evapotranspiration, determined by an average of the $\mathrm{ET}_{\mathrm{C}}$ and $\mathrm{ET}_{\mathrm{RS}}$ methods, was $13.2 \mathrm{~mm} / \mathrm{mo}$. This value represents the best estimate of the difference in evapotranspiration between the grassland and huisache sites and potential difference in increased water available for surface-water runoff or groundwater recharge at the grassland site compared with the huisache site. 
Rainfall conditions during the study were average to above average and did not include an extended dry period. As a result, differences in evapotranspiration between grassland and the huisache sites might be less pronounced during dry periods.

A map of remotely sensed annual evapotranspiration for 2015 was generated for an approximately 400-square-kilometer area surrounding the study area. The map demonstrates the capability of remote sensing to evaluate land-management effects on evapotranspiration for larger scale areas, such as a county or stream-basin area.

\section{References Cited}

Abatzoglou, J.T., 2013, Development of gridded surface meteorological data for ecological applications and modeling: International Journal of Climatology, v. 33, no. 1, p. 121-131, accessed August 12, 2019, at https://doi.org/10.1002/joc.3413.

Allen, R.G., Burnett, B., Kramber, W., Huntington, J., Kjaersgaard, J., Kilic, A., Kelly, C., and Trezza, R., 2013, Automated calibration of the METRIC-Landsat evapotranspiration process: Journal of the American Water Resources Association (JAWRA), v. 49, no. 3, p. 563-576, accessed August 12, 2019, at https://doi.org/10.1111/ jawr.12056.

Allen, R.G., Pereira, L.S., Smith, M., Raes, D., and Wright, J.L., 1996, FAO-56 dual crop coefficient method for estimating evaporation from soil and application extensions: Journal of Irrigation and Drainage Engineering, American Society of Civil Engineers, January/February 2005, accessed October 15, 2019, at https://pubag.nal.usda.gov/ download/39505/PDF.

Allen, R.G., Tasumi, M., and Trezza, R., 2007, Satellitebased energy balance for Mapping Evapotranspiration With Internalized Calibration (METRIC) - Model: Journal of Irrigation and Drainage Engineering, v. 133, no. 4, p. 380-394, accessed November 1, 2019, at https://doi. org/10.1061/(ASCE)0733-9437(2007)133:4(380).

Allen, R.G., Walter, I.A., Elliot, R.L., Howell, T.A., Ienfisu, D., Jensen, M.E., and Snyder, R.L., eds., 2005, The ASCE standardized reference evapotranspiration equation: American Society of Civil Engineers-Environmental and Water Resources Institute, Task Committee on Standardization of Reference Evapotranspiration of the Environmental and Water Resources Institute of American Society of Civil Engineers, 216 p, accessed November 1, 2019, at https://doi. org/10.1061/9780784408056.

Ansley, R.J., and Hart, C.R., 2012, Drivers of vegetation change on Texas rangelands: Texas A\&M AgriLife Extension Publication No. L-5534, 6 p., accessed November 4, 2019, at https://agrilife.org/vernon/ files/2012/11/ANS2012-02-Ansley-Hart-TALES-L5534.pdf.
Baldocchi, D.D., 2003, Assessing the eddy covariance technique for evaluating carbon dioxide exchange rates of ecosystems: Past, present, and future: Global Change Biology, v. 9, no. 4, p. 479-492, accessed November 4, 2019, at https://doi.org/10.1046/j.13652486.2003.00629.x.

Banta, J.R., and Slattery, R.N., 2011, Effects of brush management on the hydrologic budget and water quality in and adjacent to Honey Creek State Natural Area, Comal County, Texas, 2001-10: U.S. Geological Survey Scientific Investigations Report 2011-5226, 35 p., accessed November 19, 2019, at https://doi.org/10.3133/ sir20115226.

Bontrager, O.E., Scifres, C.J., and Drawe, D.L., 1979, Huisache control by power grubbing: Journal of Range Management, v. 32, no. 3, accessed May 29, 2019, at https://doi.org/10.2307/3897119.

Bray, W., 1904, The timber of the Edwards Plateau of Texas; its relation to climate, water supply, and soil: U.S. Department of Agriculture, Bulletin No. 49, 80 p., accessed November 5, 2019, at https://archive.org/details/ timberofedwardsp49bray/page/n1.

Brutsaert, W., 1982, Evaporation into the atmosphere: Boston, Springer, 302 p., accessed November 4, 2019, at https://doi.org/10.1007/978-94-017-1497-6.

Burba, G., 2013, Eddy covariance method for scientific, industrial, agricultural, and regulatory application-A field book on measuring ecosystem gas exchange and areal emission rates: Lincoln, Nebr., LI-COR Biosciences, 331 p.

Burt, R., ed., 2014, Soil survey field and laboratory methods manual: U.S. Department of Agriculture, Soil Survey Investigations Report No. 51, version 2.0, 457 p., accessed May 15, 2019, at https://www.nrcs.usda.gov/Internet/FSE_ DOCUMENTS/stelprdb1244466.pdf.

Campbell Scientific, Inc., 2016, HFP01 soil heat flux plate, revision 7/12: Logan, Utah, Campbell Scientific, Inc., instruction manual, accessed May 1, 2019, at https://s.campbellsci.com/documents/ca/manuals/hfp01_ man.pdf.

Campbell Scientific, Inc., 2019, CSAT3 three-dimensional sonic anemometer, revision 4/17: Logan, Utah, Campbell Scientific, Inc., instruction manual, accessed May 2, 2019, at http://s.campbellsci.com/documents/us/manuals/csat3.pdf.

Carroll, R.W.H., Pohll, G.M., Morton, C.G., and Huntington, J.L., 2015, Calibrating a basin-scale groundwater model to remotely sensed estimates of groundwater evapotranspiration: Journal of the American Water Resources Association, v. 51, no. 4, p. 1114-1127, accessed November 5, 2019, at https://doi.org/10.1111/jawr.12285. 
Decagon Devices, 2019, EC-20, EC-10, EC-5 soil moisture sensors user's manual, version 10: Accessed November 19, 2019, at http://manuals.decagon.com/ Retired\%20and\%20Discontinued/Manuals/EC-20-EC10-EC-5-Soil-Moisture-Sensor-Operators-Manual(discontinued).pdf.

Dugas, W.A., Hicks, R.A., and Wright, P., 1998, Effect of removal of Juniperus ashei on evapotranspiration and runoff in the Seco Creek watershed: Water Resources Research, v. 34, no. 6, p. 1499-1506, accessed July 8, 2019, at https://doi.org/10.1029/98WR00556.

Dyer, A.J., 1961, Measurements of evaporation and heat transfer in the lower atmosphere by an automatic eddy covariance technique: Quarterly Journal of the Royal Meteorological Society, v. 87, no. 373, p. 401-412, accessed November 20, 2019, at https://doi.org/10.1002/ qj. 49708737311.

Fan, S.M., Wofsy, S.C., Bakwin, P.S., Jacob, D.J., and Fitzjarrald, D.R., 1990, Atmosphere-biosphere exchange of $\mathrm{CO}_{2}$ and $\mathrm{O}_{3}$ in the central Amazon forest: Journal of Geophysical Research, v. 95, no. D10, p. 16851-16864, accessed November 20, 2019, at https://doi.org/10.1029/ JD095iD10p16851.

Foken, T., 2008, The energy balance closure problemAn overview: Ecological Applications, v. 18, no. 6, p. 1351-1367, accessed November 5, 2019, at https://doi. org/10.1890/06-0922.1.

Foken, T., Gockede, M., Mauder, M., Mahrt, L., Amiro, B.D., and Munger, J.W., 2004, Post-field data quality control, in Lee, X., Massman, X., and Law, B., eds., Handbook of micrometeorology: A guide for surface flux measurements: Dordrecht, Kluwer Academic, p. 181-208, accessed November 5, 2019, at https://doi.org/10.1007/14020-2265-4_9.

Foken, T., Leuning, R., Oncley, S.R., Mauder, M., and Aubinet, M., 2012, Corrections and data quality control, in Aubinet, M., Vesala, T., and Papale, D., eds., Eddy covariance-A practical guide to measurement and data analysis: Springer Atmospheric Sciences, p. 85-131, accessed November 5, 2019, at https://www.researchgate. net/publication/265220856_Corrections_and_Data_ Quality_Control.

Garcia, C.A., Huntington, J.M., Buto, S.G., Moreo, M.T., Smith, J.L., and Andraski, B.J., 2015, Groundwater discharge by evapotranspiration, Dixie Valley, westcentral Nevada, March 2009-September 2011 (ver. 1.1, April 2015): U.S. Geological Survey Professional Paper 1805, 90 p., accessed July 2, 2019, at https://doi. org/10.3133/pp1805.
Gash, J.H.C., and Culf, A.D., 1996, Applying linear detrend to eddy correlation data in realtime: BoundaryLayer Meteorology, v. 79, no. 3, p. 301-306, accessed November 19, 2019, at https://doi.org/10.1007/ BF00119443.

Gill Instruments, 2019, 3-Axis Anemometer, WindMaster Pro product brochure, accessed April 23, 2019, at http://www.gillinstruments.com/products/anemometer/ windmaster-pro.html.

Griffith, G.E., Bryce, S.B., Omernik, J.M., and Rogers, A., 2007, Ecoregions of Texas: Project report to the Texas Commission on Environmental Quality, 136 p., accessed September 24, 2019, at https://texashistory.unt.edu/ ark:/67531/metapth640838/.

Helsel, D.R., and Hirsch, R.M., 2002, Statistical methods in water resources: U.S. Geological Survey Techniques of Water-Resources Investigations, book 4, chap. A3, 510 p., accessed November 19, 2019, at https://doi.org/10.3133/ twri04A3.

Hukseflux Thermal Sensors, 2016, User manual HFP01 \& HFP03 heat flux plate / heat flux sensor, manual v1721: The Netherlands, Hukseflux Thermal Sensors B.V., accessed May 20, 2019, at https://www.hukseflux.com/products/heatflux-sensors/heat-flux-meters/hfp01-heat-flux-sensor.

Kipp \& Zonen, 2019, CNR4 net radiometer product brochure: Accessed April 23, 2019, at https://www.kippzonen.com/ Product/85/CNR4-Net-Radiometer\#.XMDD9-hKhaQ.

Kljun, N., Calanca, P., Rotach, M.W., and Schmid, H.P., 2004, A simple parameterisation for flux footprint predictions: Boundary-Layer Meteorology, v. 112, no. 3, p. 503-523, accessed August 15, 2019, at https://doi.org/10.1023/ B:BOUN.0000030653.71031.96.

Kormann, R., and Meixner, F.X., 2001, An analytical footprint model for non-neutral stratification: Boundary Layer Meteorology, v. 99, no. 2, p. 207-224, accessed November 5, 2019, at https://doi. org/10.1023/A:1018991015119.

Kustas, W.P., and Norman, J.M., 2009, Use of remote sensing for evapotranspiration monitoring over land surface: Hydrological Sciences Journal, v. 41, no. 4, p. 495-516, accessed November 19, 2019, at https://doi. org/10.1080/02626669609491522.

Laczniak, R.J., DeMeo, G.A., Reiner, S.R., Smith, J.L., and Nylund, W.E., 1999, Estimates of ground-water discharge as determined from measurement of evaporation, Ash Meadows area, Nye County, Nevada: U.S. Geological Water Resources Investigations Report 99-4079, 70 p., 2 pls., accessed May 29, 2019, at https://doi.org/10.3133/ wri994079. 
Law, B.E., Loescher, H.W., Boden, T.A., Hargrove, W.W., and Hoffman, F.M., 2005, AmeriFlux site evaluation and recommendations for network enhancement: Oakridge National Laboratory, accessed November 20, 2018, at http:// citeseerx.ist.psu.edu/viewdoc/download?doi=10.1.1.187.53 $56 \&$ rep $=$ rep $1 \&$ type $=$ pdf.

Leuning, R., van Gorsel, E., Massman, W.J., and Isaac, P.R., 2012, Reflections on the surface energy imbalance problem: Agricultural and Forest Meteorology, v. 156, p. 65-74, accessed November 6, 2019, at https://doi.org/10.1016/j. agrformet.2011.12.002.

LI-COR Biosciences, 2016, EddyPro software instruction manual, 12th ed.: 322 p., accessed May 15, 2019, at https:// www.licor.com/env/support/EddyPro/manuals.html.

LI-COR Biosciences, 2019a, LI-7500A open path $\mathrm{CO}_{2} / \mathrm{H}_{2} \mathrm{O}$ gas analyzer product brochure: Accessed April 23, 2019, at https://www.licor.com/documents/flfufmgemzs7pb4qq9y1.

LI-COR Biosciences, 2019b, Soil temperature sensor 7900180 installation guide: Accessed November 19, 2019, at https://www.licor.com/documents/ds1o2hon58pbbs3feen7.

Liebethal, C., Huwe, B., and Foken, T., 2005, Sensitivity analysis for two ground heat flux calculation approaches: Agricultural and Forest Meteorology, v. 132, issues 3-4, p. 253-262, accessed November 8, 2019, at https://doi. org/10.1016/j.agrformet.2005.08.001.

Liu, Y., Zhang, L. B., Hao, L., Sun, G., Liu, S. C., 2016, Evapotranspiration and land surface process responses to afforestation in western Taiwan: A comparison between dry and wet weather conditions: American Society of Agricultural and Biological Engineers, v. 59, issue 2, p. 635-646, accessed November 12, 2019, at https://doi. org/10.13031/trans.59.11110.

Mauder, M., and Foken, T., 2006, Impact of post-field data processing on eddy covariance flux estimates and energy balance closure: Meteorologische Zeitschrift, v. 15, no. 6, p. 597-609, accessed November 8, 2019, at https://doi. org/10.1127/0941-2948/2006/0167.

Moreo, M.T., Andraski, B.J., and Garcia, C.A., 2017, Groundwater discharge by evapotranspiration, flow of water in unsaturated soil, and stable isotope water sourcing in areas of sparse vegetation, Amargosa Desert, Nye County, Nevada: U.S. Geological Survey Scientific Investigations Report 2017-5079, 55 p. [Also available at https://doi. org/10.3133/sir20175079.]

Mutz, J.L., Scifres, C.J., Drewe, D.L., Box, T.W., and Whitson, R.E., 1978, Range vegetation after mechanical brush treatments on the coastal prairie: Texas Agricultural Experiment Station Bulletin 1191, 20 p., accessed November 19, 2019, at https://oaktrust.library.tamu.edu/ handle/1969.1/94181?show=full.
National Aeronautics and Space Administration, 2019a, Landsat 8: Accessed August 23, 2019, at https://landsat. gsfc.nasa.gov/landsat-data-continuity-mission/.

National Aeronautics and Space Administration, 2019b, The Enhanced Thematic Mapper Plus, Landsat Science: Accessed August 23, 2019, at https://landsat.gsfc.nasa.gov/ the-enhanced-thematic-mapper-plus/.

National Aeronautics and Space Administration, 2019c, The Worldwide Reference System, Landsat Science: Accessed August 23, 2019, at https://landsat.gsfc.nasa.gov/theworldwide-reference-system/.

National Oceanic and Atmospheric Administration, 2019, National Centers for Environmental Information, Climate Data Online data tools: Accessed April 17, 2019, at https:// www.ncdc.noaa.gov/cdo-web/datatools/.

Natural Resources Conservation Service, 2019, Web soil service: Accessed May 28, 2019, at https://websoilsurvey. sc.egov.usda.gov/App/WebSoilSurvey.aspx.

NovaLynx Corporation, 2019, Model 260-2500 and 260-250012 tipping bucket rain gauge user's manual: Auburn, Calif., NovaLynx Corporation, 18 p., accessed August 23, 2019, at https://novalynx.com/manuals/260-2500-manual.pdf.

Powell, J., Box, T.W., and Baker, C.V., 1972, Growth rate of sprouts after top removal of huisache (Acacia farnesiana [L.] Willd.) (Leguminosae) in south Texas: The Southwestern Naturalist, v. 17, no. 2, p. 191-195, accessed November 8, 2019, at https://doi.org/10.2307/3670373.

Saleh, A., Wu, J., Brown, C.S., Teagarden, F.M., McWilliams, S.M., Hauck, L.M., and Millican, J.S., 2009, Effect of brush control on evapotranspiration in the North Concho River watershed using the eddy covariance technique: Journal of Soil and Water Conservation, v. 64, no. 5., p 336-349, accessed November 12, 2019, at https://doi.org/10.2489/ jswc.64.5.336.

Scifres, C.J., 1974, Salient aspects of huisache seed germination: Southwestern Naturalist, v. 18, no. 4, p. 383-391, accessed November 9, 2019, at https://doi. org/10.2307/3670296.

Senay, G.B., 2018, Satellite psychrometric formulation of the Operational Simplified Surface Energy Balance (SSEBop) model for quantifying and mapping evapotranspiration: Applied Engineering in Agriculture, American Society of Agricultural and Biological Engineers, v. 34, no. 3, p 555-566, accessed November 13, 2019, at https://doi. org/10.13031/aea.12614.

Slattery, R.N., 2020, Evapotranspiration measured at two rangeland sites in Victoria County, south-central Texas, 2015-2018: U.S. Geological Survey data release, https:// doi.org/10.5066/P950QSRE. 
Stannard, D.I., Gannett, M.W., Polette, D.J., Cameron, J.M., Waibel, M.S., and Spears, J.M., 2013, Evapotranspiration from wetland and open-water sites at Upper Klamath Lake, Oregon, 2008-2010: U.S. Geological Survey Scientific Investigations Report 2013-5014, 66 p. [Also available at https://doi.org/10.3133/sir20135014.]

Sutron Corporation, 2019, 9210B Xlite data logger, operations and maintenance manual: Sterling, Va., Sutron Corporation, 333 p., accessed May 9, 2019, at https://www.sutron.com/ documents/xlite-9210b-user-manual-3.pdf.

Szilagyi, J., and Jozsa, J., 2013, MODIS-aided statewide net groundwater-recharge estimation in Nebraska: Ground Water, v. 51, no. 5, p. 735-744, accessed November 5, 2019, at https://www.ncbi.nlm.nih.gov/pubmed/23216050.

Tennesen, M., 2008, When juniper and woody plants invade, water may retreat: Science, v. 332, no. 5908, p. 1630-1631, accessed November 9, 2019, at https://science.sciencemag. org/content/322/5908/1630.

Teveni, P.C., III, 2017, Characterizing temporal ecophysiology for chemical management of huisache (Acacia farnesiana [L.] Willd.): Lubbock, Texas Tech University, Ph.D. dissertation, 109 p., accessed May 31, 2019, at https://ttu-ir. tdl.org/handle/2346/73170.

Thurow, T.L., and Hester, W.H., 1997, How an increase or reduction in juniper cover alters rangeland hydrology: Juniper Ecology and Management, 1997 Juniper Symposium, chap. 4, accessed March 9, 2011, at https:// texnat.tamu.edu/library/symposia/juniper-ecology-andmanagement/how-an-increase-or-reduction-in-junipercover-alters-rangeland-hydrology/.

Twine, T.E., Kustas, W.P., Norman, J.M., Cook, D.R., Houser, P.R., Meyers, T.P., Prueger, J.H., Starks, P.J., and Wesely, M.L., 2000, Correcting eddy-covariance flux underestimates over a grassland: Agricultural and Forest Meteorology, v. 103, p. 279-300, accessed November 8, 2019, at https://doi. org/10.1016/S0168-1923(00)00123-4.

University of Idaho, 2019, Climatology Lab-GRIDMET: Accessed July 15, 2019, at http://www.climatologylab.org/ gridmet.html.
U.S. Geological Survey, 2005, Office of Surface Water Technical Memorandum No. 2006.01, revised December 2009 - Collection, quality assurance, and presentation of precipitation data: Accessed June 1, 2011, at https://water.usgs.gov/admin/memo/SW/sw06.012_ Revised_122009.pdf.

U.S. Geological Survey, 2019a, Evapotranspiration and the water cycle: U.S. Geological Survey, Water Science School, accessed May 29, 2019, at https://www.usgs.gov/specialtopic/water-science-school/science/evapotranspirationand-water-cycle?qt-science_center_objects $=0 \#$ qt-science center_objects.

U.S. Geological Survey, 2019b, USGS water data for the Nation: U.S. Geological Survey National Water Information System database, accessed November 15, 2019, at https:// doi.org/10.5066/F7P55KJN.

Vaisala, 2019, Vaisala HUMICAP humidity and temperature probe HMP155, users guide: Helsinki, Finland, Vaisala Oyj, 81 p., accessed May 20, 2019, at https:/www.vaisala.com/ sites/default/files/documents/HMP155_User_Guide_in_ English.pdf.

Van Auken, O.W., 2000, Shrub invasions of North American semiarid grasslands: Annual Review of Ecology and Systematics, v. 31, p. 197-215, accessed August 23, 2019, at https://doi.org/10.1146/annurev.ecolsys.31.1.197.

Western States Water Use Program, 2019, Python implementation of the METRIC model, accessed September 16, 2019, at https://github.com/WSWUP/pymetric.

Wilczac, J. M., Oncley, S. P., and Stahe, S. A., 2001, Sonic Anemometer Tilt Correction Algorithms: Boundary-Layer Meteorology, v. 99, no. 1, accessed September 23, 2019, at https://doi.org/10.1023/A:1018966204465.

Zhang, Y., Chiew, F.H., Zhang, L., and Li, H., 2009, Use of remotely sensed actual evapotranspiration to improve rainfall-runoff modeling in Southeast Australia: Journal of Hydrometeorology, v. 10, no. 4, p. 969-980, accessed September 23, 2019, at https://doi. org/10.1175/2009JHM1061.1. 

For more information about this publication, contact

Director, Oklahoma-Texas Water Science Center

U.S. Geological Survey

1505 Ferguson Lane

Austin, TX 78754-4501

For additional information visit

https://www.usgs.gov/centers/tx-water

Publishing support provided by Lafayette Publishing Service Center 

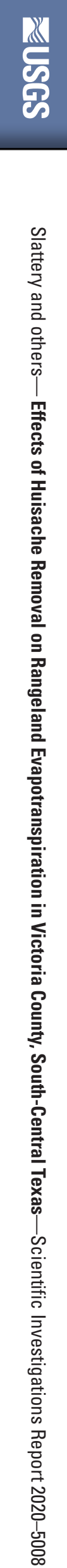

ISSN 2328-0328 (online) 